\title{
The genetic changes of Wilms tumour
}

Taryn Dora Treger ${ }^{1,2,4}$, Tanzina Chowdhury ${ }^{3}$, Kathy Pritchard-Jones ${ }^{3,4}$, Sam Behjati ${ }^{1,2,3}$

Author affiliations:

1: Wellcome Sanger Institute, Cambridge, UK

2: Department of Paediatrics, University of Cambridge, UK

3: Great Ormond Street Hospital for Children NHS Foundation Trust, London, UK

4: UCL Great Ormond Street Institute of Child Health, London, UK

\begin{abstract}
:
Wilms tumour is the most common renal malignancy of childhood. It is curable in the majority of children, albeit at considerable cost in terms of treatment related late effects in some children. In the small group of 'high risk' Wilms tumours, the prognosis is much worse. Overall, one in ten children with Wilms tumour will still die of their disease despite modern treatment approaches.
\end{abstract}

The genetic changes underpinning Wilms tumour have been defined by studies of familial cases and more recently, by unbiased DNA sequencing of tumour genomes. Together these have defined the landscape of cancer genes that are operative in Wilms tumour. Many are intricately linked to control of fetal nephrogenesis. Here, we review our current understanding of germline and somatic genetic changes that underlie Wilms tumour.

\section{A - Introduction}

\section{A1. Brief overview}

\subsection{What is it?}

Wilms tumour (WT), also known as nephroblastoma, is one of the so-called embryonal tumours of childhood, due to its histological mimicry of stages in nephrogenesis and its early age of onset. It accounts for $90 \%$ of childhood renal tumours and constitutes $7 \%$ of all childhood cancers(1). Thought to arise from aberrant nephrogenesis, many of the genetic changes underpinning WT occur in genes involved in fetal nephrogenesis(2). Although our understanding of tumourigenesis remains incomplete, the WNT pathway and insulin-like growth factor (IGF) signaling have long been considered to have pathogenic roles.

This review follows recent large scale analyses interrogating the somatic basis of WT. The genetic changes underpinning WT are diverse, driven by an array of almost 40 cancer genes (Table 1). Such diversity is particularly surprising given the monotonous driver landscape of other childhood renal tumours, such as clear cell sarcoma of the kidney (CCSK) or congenital mesoblastic nephroma (CMN). In comparison to adult cancers, the median somatic mutation rate is far lower in WT, 0.17 per million bases 
$(\mathrm{Mb})$ versus 1-10 per $\mathrm{Mb}$ across adult papillary and clear cell renal cell carcinoma $(3,4)$. Whole exome sequencing has identified recurrent and unique mutations in the microRNA processing genes and the transcription factors SIX1/SIX2(5-8). A recent whole genome sequencing study defined novel mutations in proteins involved in histone modification during nephrogenesis (BCOR, MAP3K4), proteins that interact with MYCN $(N O N O, M A X)$ and proteins involved in transcriptional repression (BCORL1), amongst others(9).

\subsection{Who gets it?}

In almost $90 \%$ of cases, WT is a sporadic event occurring in one kidney. There is a narrow developmental window for WT, with a median age of diagnosis around 3 years and $95 \%$ of cases diagnosed in children under 10 years(10). Bilateral and multifocal tumours, or WT on a background of a predisposition syndrome, tend to present earlier. This latter group includes children with WT1-associated congenital malformation syndromes (WT-anirida-genitourinary malformation-mental retardation (WAGR), Denys-Drash, Frasier) and other urogenital malformation anomalies(11). Those with WT associated with asymmetric overgrowth (Beckwith-Wiedemann syndrome and isolated hemi-hypertrophy) tend to present at the more typical age. Familial WT pedigrees exist, account for 1-2\% of cases and are known to involve several different heritable mutations(12). WT rarely occurs in adults, in whom the prognosis is worse than in children. It is believed that initial misdiagnosis and treatment related toxicity contribute to this poorer outcome(13).

\subsection{Epidemiology?}

The annual worldwide incidence of WT is approximately 1 in 100,000. The highest incidence rates are found in children of African descent and the rates for WT in East Asian populations is around half that of Caucasian children $(1,14)$. Most countries observe a female predominance of 1.1-1.2:1, though a male prevalence is observed amongst Asian children(15,16).

In the developed world overall survival approaches $90 \%$. There is however significant treatment related morbidity, both acutely and in the long-term. A proportion of children treated with current protocols are at risk of cardiac dysfunction secondary to anthracycline use, subfertility following the use of alkylating agents, second malignancies and radiotherapy-induced toxicity, including organ dysfunction and skeletal abnormalities(17). Almost $15 \%$ of children relapse and despite intensive treatment regimens, approximately half of these patients do not survive(18).

Furthermore a considerable proportion of relapses occur in patients deemed standardrisk at diagnosis.

The treatment of WT can be considered a success story, with clear management pathways delineated for most children. However, the management of bilateral disease needs continual refinement to optimise renal parenchymal preservation while maximising cure in patients who often have a tumour predisposition syndrome. The 
poor prognosis of high-risk tumours and relapsed disease is also a major challenge requiring improved understanding of oncogenesis and development of novel agents to improve outcome. In addition, survival drops significantly in low income countries and in sub-Saharan Africa, to 39\%(19). A further priority is to reduce the burden of treatment by identifying low-risk patients in whom further reduction of therapy is feasible while maintaining excellent survival. It is necessary to first provide an overview of these clinical challenges, before exploring how recent advances in our understanding of the genetic landscape of WT may contribute to improved survival.

\section{A2. Main clinical challenges}

\subsection{Current treatment strategies highlighting the differences between the SIOP and the US approach}

There are two different philosophies for managing children diagnosed with a renal tumour. In Europe, the majority of children with WT receive pre-operative chemotherapy in line with Société Internationale d'Oncologie Pédiatrique Renal Tumours Study Group (SIOP-RTSG) protocols(20). Tumours in infants younger than 6 months of age are usually managed with primary nephrectomy, as in this group nonWT renal tumours are a more likely diagnosis. The aims of pre-operative chemotherapy are to treat micrometastases at diagnosis, to evaluate tumour response and to reduce the risk of intra-operative rupture(21). Most children receive actinomycin $\mathrm{D}(\mathrm{AD})$ and vincristine (VCR), with the addition of doxorubicin (DOX) in metastatic cases. Chemotherapy is commenced without a confirmatory biopsy in most European countries, owing to the diagnostic likelihood of a renal mass in a child above six months being a WT and the potential risks associated with biopsy(22). Conversely, in North America most children undergo immediate nephrectomy as per the National Wilms' Tumour Study/Children's Oncology Group (COG). This approach provides a chemo-naïve histopathologic diagnosis, and reduces exposing children with benign and non-WT malignant renal tumours to inappropriate cytotoxic chemotherapy. In addition it allows early classification of stage to allow subsequent risk-stratified oncological therapy.

Both groups use stage of disease and histological subtype to stratify post-operative chemotherapy and, for higher risk patients, radiotherapy. SIOP classifies tumours as low- (completely necrotic and cystic), intermediate- (epithelial, stromal, regressive or mixed subtype, including focal anaplasia) or high-risk (blastemal type and diffuse anaplasia). COG characterises histology as favourable (i.e. 'non-anaplastic') or unfavourable (focal and diffuse anaplasia). Blastemal subtype, identified by the percentage of blastema remaining following pre-operative chemotherapy, is classified as high-risk by SIOP. By contrast, COG includes all histological appearances other than the presence of anaplasia in a treatment-naïve tumour as favourable histology. Since 2005, COG have included a molecular marker, loss of heterozygosity (LOH) for alleles spanning chromosomes $1 \mathrm{p}$ and $16 \mathrm{q}$ (1p36.12p36.11 and 16q22.1q24.3 respectively) into risk stratification, treating children whose tumours have combined $1 \mathrm{p} / 16 \mathrm{q}$ LOH with more intensive chemotherapy $(23,24)$. Although the method of 
oncogenesis in tumours with combined $1 \mathrm{p} / 16 \mathrm{q} \mathrm{LOH}$ remains uncertain, this biomarker is significantly associated with risk of relapse and death in all stage disease. Regarding stage, only COG upstages children who have undergone biopsy from stage 1 to stage 3. Uniquely, COG stratification identifies a group of very low risk tumours that do not receive adjuvant cytotoxic treatment, i.e. children younger than 2 years with stage I favourable histology and tumour weight less than $550 \mathrm{~g}$ as very low-risk(25). All other children receive post-operative chemotherapy with VCR and ACT-D, with the addition of DOX for metastatic disease and stage I high-risk tumours. High-risk tumours with advanced stage are treated with carboplatin (CDC)/ etoposide (ETO)/ cyclophosphamide (CYC)/ DOX. Two year event free and overall survival rates for children treated with the most recent large scale European trial (SIOP-2001) were $87 \%$ and $93 \%$ respectively, with similar results reported in COG trials $(26,27)$.

\subsection{Standard risk children who relapse}

Relapse in WT occurs in approximately $15 \%$ of treated patients, mostly within two years of diagnosis(18). Common relapse sites include the lung, abdomen and liver, and only rarely does WT disseminate to the bone or brain. Overall survival varies between 10\% - 70\% depending on initial treatment, relapse site and histology (2831). Prognostic factors for recurrence are not fully understood and more than half of all relapses occur in patients without known risk factors. In SIOP-2001, relapse rates amongst 3559 children were $26 \%$ in high-risk, $11 \%$ in intermediate-risk and 5\% in low-risk(26). In very low-risk cases, as defined by COG, relapse occurs in up to $15 \%(32)$. In this group, only $\mathrm{LOH}$ at $11 \mathrm{p} 15$ has been reproducibly associated with disease recurrence $(25,33)$. For all histological risk groups, gain of 1q consistently predicts poorer event free survival(34-36). In the COG cohort, gain of 1q is also associated with a reduction in overall. Although this is the most promising molecular biomarker, affecting $28 \%$ of all WT, the driver mechanisms underlying gain of $1 \mathrm{q}$ remain unknown.

\subsection{Anaplasia}

Anaplasia, defined as the presence of cells with nuclear enlargement, hyperchromasia and abnormal mitotic figures, is found in less than $10 \%$ of WT(37). Diffuse anaplasia (DAWT), classified as high-risk and unfavourable histology by SIOP and COG respectively, is frequently associated with poorer outcome. Somatic mutation of the tumour suppressor gene TP53 underlies up to $60 \%$ of anaplastic tumours(38-40). Mutations are limited to anaplastic regions and are rarely seen in other histological subtypes. However, a recent analysis of fatal tumours found mutant TP53 in 26\% of non-anaplastic cases, suggesting variant TP53 may be a clonal event preceding the development of anaplasia(41). In advanced stage disease, these mutations are associated with an increased risk of relapse and mortality, when compared to wildtype TP53 DAWT. Despite this association, genetic testing of tumours is not yet routinely undertaken and all patients with DAWT are stratified to receive more intensive treatment. 


\subsection{Bilateral tumours}

Bilateral or stage $\mathrm{V}$ disease, whereby WT or precursor lesions known as nephrogenic rests (NR) affect both kidneys, is found in 5-8\% of cases(42). Both kidneys are usually affected simultaneously and only in less than $1 \%$ of cases is disease metachronous(1). Patients tend to present under 2 years of age and there is a marked female preponderance. In a recent review of 545 bilateral cases, $22 \%$ of children had predisposition syndromes(43). There is a strong association with germline genetic and epigenetic abnormalities, with WT1 loss and 11p15 loss of imprinting predominating. Management remains challenging, particularly in the context of WT1 mutation syndromes associated with inherent predisposition to nephropathy and the morbidity associated with persistent hypertension. Both SIOP and COG protocols initiate preoperative chemotherapy followed by nephron-sparing surgery, with the aim of achieving cure whilst preserving maximal renal function (NSS).

\subsection{Long term morbidity, in particular renal and cardiac morbidity}

Current treatment protocols leave a proportion of patients at risk of renal and cardiac failure, hypertension, metabolic syndrome, infertility, secondary cancers and abnormal musculoskeletal development(17). The last long-term follow up identified that almost a quarter of survivors experience severe chronic and life-threatening health conditions in adulthood, although this cohort was treated as far back as the 1980s(44). The incidence of end stage renal failure (ESRF) stands at $1 \%$ for unilateral disease, increasing to $10 \%$ for patients with bilateral WT(45). Highest rates of ESRF are found in patients with DDS and WAGR syndrome, at $74 \%$ and $36 \%$ respectively. The risk of congestive cardiac failure is related to the cumulative dose of DOX administered, ranging from about $5 \%$ for patients receiving DOX during initial treatment to $17 \%$ for relapsed cases(46). Females and infants are particularly susceptible and risk is potentiated by both pulmonary and abdominal radiotherapy. To avoid cardiotoxicity, DOX is no longer recommended for the treatment of small volume $(<500 \mathrm{~mL})$ stage II-III intermediate-risk histology WT $(20,47)$. Similarly, pulmonary radiotherapy can be omitted for lung lesions that demonstrate complete response to chemotherapy(48). Although both approaches carry a minimal increased risk of relapse, second remission is usually achieved.

\subsection{Wilms in low-and middle income countries}

Over $80 \%$ of all childhood cancers are diagnosed in children living in low and middle-income countries(49). This significant cancer burden in resource poor settings is associated with poorer outcomes. Even across Europe, there is some variation in overall survival rates, down to $83.9 \%$ (50). In sub-Saharan Africa failure of treatment most commonly results from abandonment. As a consequence, in this region overall survival ranges from 11-61\%(8). Improvements in survival through international collaboration have been demonstrated in several centres, with adoption of amended SIOP protocols, better supportive care and the establishment of multidisciplinary teams $(51,52)$. 


\section{B - Main sections and subsections}

\section{B1. Cancer genes operative in Wilms tumour}

\subsection{Nephrogenesis}

The definitive kidney anlage, metanephros, forms at around the fifth week of gestation from the intermediate mesoderm, through a sequence of reciprocal and complex tissue interactions(53). The earliest stage involves the interaction between the ureteric bud, a caudal outpouching of the Wolffian duct, and the metanpehric mesenchyme. As the ureteric bud invades the metanephric blastema, the cells condense and undergo mesenchymal to epithelial transition (MET), leading to early tubule formation. These early tubules will eventually become the glomerular podocytes, proximal and distal tubules and loop of Henle. The ureteric bud, itself induced to branch, forms the collecting duct system. It has long been thought that WT arises from the metanpehric mesenchyme, with gene expression correlating with early nephrogenesis(54). Recently, molecular profiles of WT with classic triphasic histology (blastemal, epithelial and stromal elements) have also matched those of the ureteric bud(55). Furthermore, many of the mutated genes found in WT are key regulators of the entire process (Figure 1).

\subsection{Germline predisposition to Wilms}

In up to $15 \%$ of cases, WT occurs on a background of a predisposition syndrome or germline mutation in cancer-risk genes (Table 2)(56,57).

The first gene to be implicated in tumorigenesis was $W T 1$ at $11 \mathrm{p} 13$. It encodes a zinc finger DNA-binding transcription factor that is non-redundant for urogenital development and glomerular function $(58,59)$. There is no recurrent loci for somatic WT1 mutations in WT. Mechanisms of WT1 inactivation include mutations affecting the DNA binding domain and mutations producing truncated proteins that lack this domain completely(60). WT1 is expressed in the metanephric and condensing mesenchyme, and its loss results in a spectrum from complete renal agenesis to disrupted differentiation depending on stage of nephrogenesis $(59,61,62)$. Over 1000 genes appear to be regulated by the two major isoforms of WT1, many of which are essential for renal development and are themselves mutated in WT(63).

The constellation of urogenital malformation, renal failure and WT susceptibility occurs in the following syndromes, all with constitutional abnormalities in the WT1 gene. WAGR syndrome (WT, anirida, genital anomaly and retardation) is caused by microdeletion of $11 \mathrm{p} 13$, including the WT1 locus and the adjacent aniridia gene PAX6. Risk of WT development is around 50\% and children present earlier with a higher incidence of bilateral tumours(64). Similarly, bilateral disease occurs in $20 \%$ of children with DDS, a syndrome characterised by ambiguous genitalia and nephropathy secondary to diffuse mesangial sclerosis(65). Missense mutations in the DNA-binding domain of WT1 underlie DDS(66). Mutations that alter WT1 splicing 
cause Frasier syndrome, phenotypically similar to DDS but with focal segmental glomerulosclerosisis and a predisposition to gonadoblastoma(67). The association of WT1 with intralobar nephrogenic rests (ILNR) suggests somatic WT1 loss may be an early event(68).

A second WT locus was subsequently identified at 11p15. Paternal uniparental disomy or maternal $H 19$ epimutation both result in biallelic expression of $I G F 2$ and overactivation of the IGF signalling pathway (50). Abnormal methylation at $11 \mathrm{p} 15$ is the most common genomic change found in WT, uniformly present in multi-sampled tumours and found in perilobar nephrogenic rests (PLNR) (70,71). Multiple germline epigenetic and genetic changes at 11p15 are responsible for Beckwith Wiedmann Syndrome (BWS). BWS is an overgrowth syndrome with increased risk of embryonal tumours including WT, neuroblastoma, hepatoblatoma and rhabdomyosarcoma. WT develops in $20 \%$ of cases, with highest risk in uniparental disomy or H19 hypermethylation(72). The most common epigenetic subgroup (hypomethylation of $K v D M R 1$ ) carries no increased risk of WT. Another generalised overgrowth syndrome with susceptibility to WT is the X-linked Simpson Golabi-Behmel syndrome.

Mutations occur in the GPC3 gene, encoding an extracellular proteoglycan involved in promoting Wnt signalling(73).

Disruption of miRNA biogenesis, through germline mutations in DIS3L2 is the basis of Perlman syndrome(74). This is a rare overgrowth syndrome with susceptibility to WT, over half of which are bilateral. Mutations in the miRNA processing gene DICER1 underlie the pleiotropic cancer susceptibility DICER1 syndrome and have been identified as a cause of familial WT(75). Two further predisposition loci were found by genetic linkage studies of affected families, occurring at 17q21(FWT1) and 19q13 (FWT2), although the genes have yet to be characterised(76,77). Finally, WT susceptibility occurs in several tumour predisposition syndromes including in LiFraumeni (TP53) and Fanconi anaemia (BRCA2, PALB2)(11).

\subsection{Recent advances in our understanding of somatic and germline changes}

Until a few years ago, the only known somatic mutations were those involving WT1, LOH at 11p15, the Wnt pathway (AMER1, CTNNB1) and the oncogene MYCN. Of these genes, only mutations in $M Y C N$ have clinicopathological association, predicting poor outcome in several childhood embryonal cancers including WT, neuroblastoma, medulloblastoma and rhabdomyosarcoma(78-81). Mutations in CTNNB1 are frequently found to occur at serine 45 , a functionally critical phosphorylation residue necessary for beta-catenin degradation(82,83). Recently, mutations in MLLT1 have been identified, often occurring alongside variant CTNNB1(84). MLLT1 orchestrates transcription during nephrogenesis.

Applying unbiased tumour genome sequencing has revealed further cancer genes that harbor likely driver mutations in WT. Whole exome sequencing has identified alterations in the epigenetic remodelers SMARCA4 and ARID1A, members of the 
BAF chromatin remodeling complex, with variants also found in medulloblastoma and atypical teratoid rhabdoid tumour (ATRT)(85-87). MicroRNA biogenesis and the miRNA processing genes DROSHA, DICER1, DGCR8, XPO5 and TARBP2 have too been implicated(5). DROSHA and DICERI mutations lead to reduced expression of the tumour-suppressor Let7 family and failure of epithelial differentiation. WT specific oncogenes that have been discovered include $S I X 1$ and $S I X 2$, encoding transcription factors with a non-redundant role in renal development $(8,88)$.

More recently, whole genome sequencing of 117 WT has added further candidates to the genetic landscape of WT(9). WT-related cancer genes now include those involved in histone modification during nephrogenesis (BCOR, MAP3K4, BRD7, CREBBP and $H D A C 4)$ and those that play a crucial role in transcriptional repression (BCORL1). BCOR and the homologous BCORL1 are ubiquitously expressed and postulated to have tumour suppressor function, with both somatic mutations and fusion transcripts identified in several other cancers(89-91). Internal tandem duplications (ITDs) of BCOR are the sole driver in a proportion of $\operatorname{CCSK}(92)$.

In addition, $N O N O$ and $M A X$ have been implicated; both genes encoding proteins that interact with MYCN, with MAX expression appearing to correlate with clinical outcome in neuroblastoma(93-95). Alterations in ACTB ( $\beta$-actin), another component of the BAF complex and $A S X L 1$, a polycomb group protein, were also identified. Polycomb proteins are recruited by WT1, leading to downregulation of Pax 2 expression, a transcriptional regulator with a vital role in urogenital development(96).

As well as representing a genetically diverse group, WT have been shown to display intra-tumoural diversity(70). Such micro-diversity has been associated with higher histological risk, advanced stage and poorer outcome in a study of 44 chemotherapyexposed SIOP tumours(97). Copy number variants (CNVs) are common and the following are not uniformly spatially distributed, gain of 1q, gain of 2p24 (MYCN locus) and $17 \mathrm{p} 13$ loss (TP53)(9,41,70). Loss of $17 \mathrm{p} 13$ is predominantly associated with anaplastic tumours, which display a characteristically unstable cancer genome with additional loss of $4 \mathrm{q}$ and $14 \mathrm{q}(98)$. Gain of $2 \mathrm{p} 24(M Y C N)$ is also associated with anaplasia, and has been reported as both a somatic and germline event(80).

Germline mutations occur in around $10 \%$ of patients with non-syndromic WT. The recent COG study identified a number of novel, putative WT predisposition genes including CHEK2, EP3OO and ARID1A(9). CHEK2 is a tumour suppressor gene contributing to hereditary breast cancer and germline mutations have been found in high grade paediatric brain tumours $(99,100)$. Germline events in another breast cancer risk gene, $P A L B 2$, were preferentially associated with diffuse anaplastic WT. Biallelic mutations in $P A L B 2$ underlying Fanconi anaemia subtype FA-N have been previously identified in familial WT(101). Another recently identified candidate tumour suppressor gene is REST, with inactivating mutations predisposing to WT(102). 
REST, a transcriptional repressor, is essential for embryogenesis and truncations in the protein occur in several other cancers including neuroblastoma(103). A second gene with a role in maintaining embryonic stem cell pluripotency is CTR9.

Constitutional CTR9 mutations are present in several WT families $(104,105)$. Homozygous loss of function mutations in TRIP13 were found in children with WT on a background of mosaic variegated anapleuoidy syndrome(106).

\subsection{MicroRNA processing genes}

Mutations in several miRNA processing genes (miRNAPGs), including DROSHA, DICER1, DGCR8, XPO5 and TARBP2, have been found in sporadic WT, in chemotherapy-naïve tumours and in tumours exposed to neoadjuvant agents $(5,8,87,88)$. The mutational hotspot in the metal-binding RNase IIIb domain of DROSHA (E1147K) appears to be unique to WT, and has not been found in other childhood or adult cancers (Table 3). Recurrent mutations in the RNA binding domains of DROSHA, DGCR8 and DICERl variant tumours lead to impaired miRNA biogenesis. Global downregulation of mature miRNAs, including the Let7 family, occurs in DROSHA mutants, with partial loss is seen in DICERI tumours(6). Let7 miRNA processing is suppressed by Lin28b. Overexpression of this RNA-binding protein during nephrogenesis leads to WT formation in mice(107). Copy number gain of LIN28B and loss of Let7 are respectively seen in $25 \%$ and $46 \%$ of WT, and interestingly, cluster separately to miRNAPG variant tumours in gene but not miRNA expression(9). A reduction of the miR-200 family is also seen alongside miRNAPG mutations. These miRNA have a crucial role in MET in the developing kidney. Their downregulation is thought to lead to failure of the process(108). Mutations in miRNAPG are associated with pre-therapy blastemal histology, PLNR and aberrant imprinting at $11 \mathrm{p} 15(88)$. The high frequency of LOI at $11 \mathrm{p} 15$ observed in tumours with combined miRNAPG and SIX1/SIX2 alterations suggest multiple events are responsible for WT tumourigenesis in blastemal subtype. This combination, although infrequent, is associated with both relapse and poor outcome.

\subsection{Unique (i.e. Wilms specific) cancer genes SIX1/SIX2}

The three studies to have identified mutations in SIX1/SIX2 all found a recurrent Q177R mutation in the DNA-binding homeodomain of these transcription factors, resulting in a glutamine to arginine substitution(7-9). Recurrent hot spot mutations in SIX1/SIX2 are unique to WT. Mutations in a different loci within the homeobox of SIX1 occur in branchio-oto-renal syndrome, characterized by a spectrum of kidney abnormalities but with no increased risk of WT(109). SIX1 and SIX2 are key regulators of nephrogenesis. SIX1 loss leads to mesenchymal apoptosis in SIX1knockout mice(110). SIX2 activity maintains the mesenchyme progenitor population in an undifferentiated blastema state(111). Cell cycle genes are upregulated in both SIX1 and SIX2 mutant WT. SIX2 overexpression in renal cell lines correlates with a higher percentage of cells in the S-phase $(7,8)$. This cumulative evidence suggests that SIX1/SIX2 have oncogenic function in a subset of tumours, driving proliferation of the metanephric mesenchyme. In WT, SIX1/SIX2 mutations have been associated with 
high-risk blastemal type in SIOP tumours and with the presence of undifferentiated blastema in chemo-naïve samples(7,8). Although the high allele frequency of SIX mutations suggests they may be an early event, an analysis of 8 paired primaryrelapse samples found it to also occur de-novo(112).

\subsection{Comparison of genetics of Wilms tumours with the other renal tumours of childhood}

The remaining $10 \%$ of non-WT renal tumours most frequently include CCSK, malignant rhabdoid tumour of the kidney (MRTK), renal cell carcinoma (RCC) and the relatively benign CMN. CCSK has a similar age distribution to WT but is not associated with familial or predisposition syndromes. There are two non-concurrent genetic events that underlie the majority of CCSK tumours; internal tandem duplications (ITDs) of $B C O R$ and translocation $\mathrm{t}(10 ; 17)(\mathrm{q} 22 ; \mathrm{p} 13)$, resulting in fusion of $Y W H A E$ and $N U T M 2 B / E(92,113,114)$. Although ITDs in BCOR have not been observed in WT, somatic mutations were found in $B C O R$ and the closely related BCORL1(9). The Xp11 translocation-RCC are the most common subtype of RCC, and involve a fusion between the transcription factor TFE3 (Xp11) and several genes including ASPL (17q25), PRCC (1q21) and PSF (1p34)(115). There are a multitude of rarer fusion partners, of which only $N O N O(\mathrm{Xq} 13)$ has also been implicated as a WTrelated cancer gene. The peak incidence of RCC is in adolescence and around 15\% of patients have previously received chemotherapy(116). Complete surgical resection is the only realistic curative therapy, and the use of multi-targeted receptor tyrosine kinase inhibition is reserved for metastatic or relapsed cases with only anecdotal evidence of efficacy. MRTK tends to occur under 2 years of age and $95 \%$ of patients have bialleic mutations in SMARCB1, another subunit of the BAF chromatin remodeling complex(117). A third of children have germline alterations in SMARCB1 which acts as an additional poor prognostic indicator for a disease with an already dismal outlook(118). CMN is usually diagnosed in infancy and has an impressive five-year survival approaching 95\%. Recurrent translocations, resulting in a fusion protein between the growth factor receptor NTRK3 and the transcription factor ETV6, are observed in the cellular and mixed subtypes of CMN(119).

\section{B2. Peculiarities of Wilms that require some thinking}

\subsection{Genetic epidemiological differences in incidence and Wilms tumour sub-types around the world}

There is epidemiological evidence to suggest the observed difference in WT incidence exists between races rather than geographical areas. The highest annual rates are seen in children of African descent (10 cases per million), the lowest in Asian populations (3 cases per million) and in Caucasians, the incidence is $6-9$ per million $(14,15,120)$. Hispanic children are noted to have a lower incidence of WT than Caucasian children and this risk varies within the population, depending on maternal birthplace $(121,122)$. These observations and the increasing repertoire of germline WT predisposition genes 
suggest genetic or epigenetic mechanisms are responsible for the observed ethnic disparity. Loss of imprinting at 11p15 and PLNR are more frequently identified in Caucasians than in both Japanese and American-born Asian children(123).

Conversely, analysis of bilateral tumours from Japanese children reveals a far higher incidence of constitutional WT1 anomalies(124). There is also apparent variation in histological subtype between races. Registration of anaplastic histology was $4.9 \%$ in the Japan Wilms' Tumor Study Group compared to $10.8 \%$ in the American National Wilms Tumor Study 5(125). Japanese children with anaplastic tumours had a lower stage of disease and good outcomes, but the number of cases was too small for direct prognostic comparison. Although a recent meta-analysis of published WT research identified mutations in WTI and WTX as more prevalent in non-Caucasians, with the reverse true for $C T N N B 1$, the differences in prevalence were not statistically significant(126). Several genome wide association studies have identified polymorphisms that infer WT susceptibility, including HACE1, BARD1, 2p24, 11q14, but none of these investigations have been carried out in a cohort with mixed ethnicity(127-129).

\subsection{Specific and near exclusive age predilection of Wilms to early childhood}

In addition to the racial disparity observed in WT incidence, age at diagnosis varies and in the US, black children are diagnosed later than their Caucasian and Asian counterparts(10). WT predominantly occurs in early childhood, with a median age of diagnosis at 3 years for sporadic WT and 2 years for bilateral or multifocal cases. There is accumulating evidence to suggest that aberrant nephrogenesis may be an initiating step in tumourigenesis, explaining the narrow developmental window of WT. The first clue is that some WTs are accompanied by the persistence of embryonic tissue, ILNRs and PLNRs, otherwise not normally present in the postnatal kidney. Furthermore in a subset of WT, methylation profiles vary during tumour evolution from NRs(130). Gene expression profiles segregate WT into five clinicallyrelevant groups, each one coupled to a developmental stage of nephrogenesis(131). The link is further supported by the mapping of cell subpopulations in fetal kidneys and $\mathrm{WT}$. NCAM ${ }^{+} \mathrm{CD} 133^{-}$represent renal stem cells in fetal kidneys and blastema in WT(132). $\mathrm{NCAM}^{+} \mathrm{CD} 133^{+}$and $\mathrm{NCAM}^{-} \mathrm{CD} 33^{+}$define immature and mature epithelia respectively. Finally, the ever-increasing number of WT related genes with pivotal roles in the developing kidney supports the hypothesis that WT are inextricably linked to renal organogenesis.

\section{How can this new knowledge of somatic cancer genes in Wilms lead to novel treatments?}

Although largely curable in the developed world, identifying novel therapeutics remains a priority for the WT subgroups with poor prognosis. A recent study highlighted that only around $19 \%$ of children with relapse/refractory WT were recruited to early phase trials over the past decade(133). The outcome for patients enrolled in previous trials of targeted therapy remains dismal. COG is aiming to 
address this by matching biological agents to actionable mutations, through its TARGET initiative(134). There are several promising avenues, particularly those involving somatic variants found in patients with relapse and/or fatal tumours.

One potential candidate is the oncogene $M Y C N$ as it is ubiquitously associated with poor outcome in many childhood cancers. MYCN was considered an 'undruggable' target prior to the advent of inhibitors of Aurora-A kinase (AURKA), which block the interaction between the two proteins resulting in MYCN degradation(135). Only 13\% of WT have variant MYCN. In a recent phase II study of alisertib, an AUKRA inhibitor, 8 out of $10 \mathrm{WT}$ patients had progressive disease(133). Objective response has been demonstrated with alisertib, as a single agent and as combination therapy in ATRT and neuroblastoma, respectively(136,137). In neuroblastoma cell lines, MYCN inactivation and growth arrest is seen with inhibition of RAS(138). The RAS superfamily ( $H-R A S, K-R A S, N-R A S)$ are the most mutated oncogenes in human cancer and have remained another elusive target(139). Although mutations in $R A S$ are rarely observed in WT, RAS expression is associated with increased WT size and identified in patients with the combination of variant $S I X$ and miRNAPG(88,140). In mice, K-RAS activation on a background of $\beta$-catenin stabilisation leads to metastatic renal tumours that closely resemble WT epithelial histology(141).

With the recent identification of mutations in epigenetic remodelers in WT, and their interaction with histone deacetylases (HDAC), inhibitors of the latter might be another promising avenue. Transient response to single agent vorinostat, an HDAC inhibitor, was demonstrated in a child with refractory anaplastic embryonal rhabdomyosarcoma harboring mutations in BCOR and ARIDIA(142). A further potential target is TP53, given the prevalence of TP53 mutants in both anaplastic and non anaplastic fatal tumours(41). There are currently no paediatric trials targeting TP53. Adult early phase trials are ongoing; to test both TP53 recombinant adenoviral human gene therapy and inhibitors of MDM2/MDMX, negative regulators of TP53(143). Another recent phase II trial of interest is the CD56-binding antibodydrug conjugate, lorvotuzumab mertansine (144). CD56 (NCAM-1) is enriched in blastema and $\mathrm{CD}^{+} 6^{+}$cells may act as cancer stem cells in a subset of tumours(145).

A more complete understanding of the genetic changes that drive WT development and progression has helped to identify potentially actionable mutations. Whether these will translate into improved survival for children with refractory, relapsed or high-risk disease remains to be seen. Our knowledge of the biological heterogeneity of WT continues to drive improvements in risk stratification through the introduction of molecular biomarkers. The next SIOP study/trial aims to validate the clinical utility of several of these promising candidates including 1q gain(20). Despite the discovery of almost 40 WT genes, the candidate genes driving oncogenesis in tumours with gain of 1q remain unknown. The outstanding objective remains to salvage the proportion of WT patients that relapse whilst, at the other end of the spectrum, to identify children with excellent prognosis in whom omission of therapy is a viable option. Further 
elucidating the underlying genetic landscape will hopefully make personalised therapy for each child with WT the norm.

\section{Conflicts of Interest}

None

\section{Funding}

TT is funded by a Cambridge Academic Clinical Fellowship. SB is funded through personal wards from the Wellcome Trust and the St. Baldrick's Foundation. KPJ is funded in part, by the National Institute of Health Research Biomedical Research Centre at Great Ormond Street Hospital, the Great Ormond Street Hospital Children's Charity and Cancer Research UK (grant no. C1188/A4614). 
Figure 1: Figure placing cancer genes in nephrogenesis
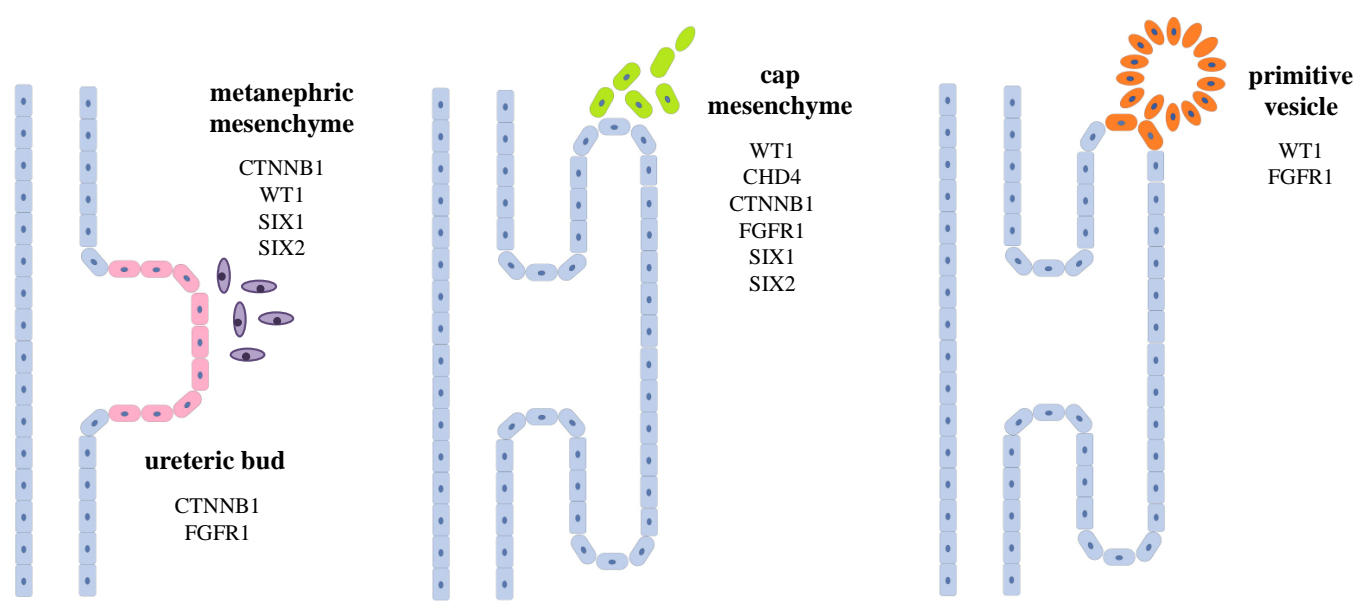
Table 1: Somatic cancer genes identified in Wilms tumour, with prevalence $>1 \%$

\begin{tabular}{|c|c|c|c|c|}
\hline Genetics & $\begin{array}{c}\text { Copy number } \\
\text { variation }\end{array}$ & $\begin{array}{c}\text { Point } \\
\text { mutation }\end{array}$ & Prevalence & Clinicopathological associations \\
\hline WT1 (11p13) & ( & ( & $10-20 \%$ & $\begin{array}{l}\text { early event, found in ILNR } \\
\text { associated with stromal histology }\end{array}$ \\
\hline$C T N N B 1(3 \mathrm{p} 21)$ & ( & ( & $15 \%$ & $\begin{array}{l}\text { late event, not in NR } \\
\text { associated with non-anaplastic histology }\end{array}$ \\
\hline$A M E R 1(\mathrm{Xq} 11)$ & ( & ( & $15-20 \%$ & no clinicopathological associations \\
\hline$I G F 2(11 \mathrm{p} 15)$ & ( & ( & $69 \%$ & $\begin{array}{l}\text { early event, found in PLNR } \\
\text { associated with epithelial /blastemal histology }\end{array}$ \\
\hline TP53 (17p13) & ( & Q & $70 \%$ & $\begin{array}{l}\text { reduced EFS and OS } \\
\text { rarely found in tumours without diffuse anaplasia }\end{array}$ \\
\hline$M Y C N(2 \mathrm{p} 24)$ & ( & ( & $13 \%$ & $\begin{array}{l}\text { reduced EFS and OS } \\
\text { associated with anaplastic histology }\end{array}$ \\
\hline miRNAPG & ( & Q & $15-18 \%$ & $\begin{array}{l}\text { found in PLNR } \\
D G C R 8 \text { has a female bias ( } 88 \% \text { of cases) } \\
\text { reduced EFS/OS when concurrent with } S I X 1 / 2\end{array}$ \\
\hline $\begin{array}{l}\text { SIX1 }(14 \mathrm{q} 23) \\
\text { SIX2 (2p21) }\end{array}$ & प & Q & $7-18 \%$ & $\begin{array}{l}\text { found in PLNR } \\
\text { reduced EFS/OS when concurrent with miRNAPG }\end{array}$ \\
\hline SMARCA4 (19p13) & ( & Q & $4.5 \%$ & not known \\
\hline MLLT1 (19p13) & ( & Q & $4 \%$ & early event, found in ILNR; younger age \\
\hline BCORL1 (Xq26) & ( & ( & $3.8 \%$ & not known \\
\hline COL6A3 (2q37) & Q & Q & $3.2 \%$ & not known \\
\hline$N F 1(17 q 11)$ & Q & Q & $2.9 \%$ & not known \\
\hline$B C O R(\mathrm{Xp} 11)$ & Q & Q & $2.6 \%$ & not known \\
\hline NONO (Xq13) & Q & Q & $2 \%$ & not known \\
\hline ARIDIA (1p36) & Q & Q & $1.8 \%$ & not known \\
\hline MAP3K4 (6q26) & Q & Q & $1.7 \%$ & not known \\
\hline$M A X(14 \mathrm{q} 23)$ & Q & प & $1.7 \%$ & not known \\
\hline$A S X L 1(20 \mathrm{q} 11)$ & Q & Q & $1.7 \%$ & not known \\
\hline BRD7 (16q12) & Q & Q & $1.5 \%$ & not known \\
\hline FGFR1 (8p11) & Q & Q & $1.4 \%$ & not known \\
\hline$H D A C 4(2 \mathrm{q} 37)$ & Q & ( & $1.2 \%$ & not known \\
\hline CHD4 (12p13) & Q & प & $1.2 \%$ & not known \\
\hline$A C T B(7 \mathrm{p} 22)$ & 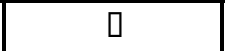 & 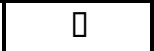 & $1.1 \%$ & not known \\
\hline
\end{tabular}


Table 2: Wilms predisposition syndromes

\begin{tabular}{|c|c|c|}
\hline WT risk & Syndrome & Genetics \\
\hline \multirow{5}{*}{$\begin{array}{l}\text { High } \\
>20 \%\end{array}$} & WAGR & WT1 deletion \\
\hline & DDS & WT1 missense mutation \\
\hline & Perlman & DIS $3 L 2$ mutation \\
\hline & Fanconi anaemia & Biallelic $B R C A 2$ mutation/ PALB2 mutation \\
\hline & Mosaic variegated aneuploidy & Biallelic $B U B 1 B / T R I P 13$ mutation \\
\hline \multirow{3}{*}{$\begin{array}{l}\text { Moderate } \\
5-20 \%\end{array}$} & Frasier & WT1 intron 9 splice mutation \\
\hline & BWS & Uniparental disomy or H19 epimutation \\
\hline & Simpson Golabi Behmel syndrome & GPC3 mutation \\
\hline \multirow{7}{*}{$\begin{array}{l}\text { Low } \\
<5 \%\end{array}$} & Bloom & Biallelic $B L M$ mutation \\
\hline & DICER1 syndrome & DICERI mutation \\
\hline & Li Fraumeni & TP53 mutation \\
\hline & Isolated hemihypertrophy & variable \\
\hline & $\begin{array}{l}\text { Hyperparathyroidism-jaw tumour } \\
\text { syndrome }\end{array}$ & CDC73/ HRPT2 mutation \\
\hline & Mulibrey nanism & TRIM37 mutation \\
\hline & PIK3CA-related segmental overgrowth & PIK3CA mutation \\
\hline
\end{tabular}


Table 3: Recurrent intragenic mutations found in Wilms tumour(146).

\begin{tabular}{|l|l|l|l|}
\hline Gene & Recurrent mutation & Number of WT cases & $\begin{array}{l}\text { Hotspot identified in other cancers } \\
\text { (number of cases) }\end{array}$ \\
\hline CTNNB1 & S45F & 35 & $\begin{array}{l}\text { soft tissue (441) } \\
\text { hepatocellular carcinoma (78) } \\
\text { colon carcinoma (77) } \\
\text { adrenocortical carcinoma (42) }\end{array}$ \\
\hline MYCN & P44L & 34 & $\begin{array}{l}\text { neuroblastoma (4) } \\
\text { endometrial carcinoma (4) } \\
\text { basal cell carcinoma (4) } \\
\text { glioma (3) } \\
\text { medulloblastoma (1) }\end{array}$ \\
\hline DROSHA & E1147K & 85 & nil \\
\hline DGCR8 & E518K & 50 & thyroid carcinoma (2) \\
\hline SIX1 & $Q 177 R$ & 29 & nil \\
\hline SIX2 & $Q 177 R$ & 23 & $\begin{array}{l}\text { nil } \\
\text { colon carcinoma (3) } \\
\text { malignant melanoma (2) } \\
\text { acute myeloid leukaemia (1) }\end{array}$ \\
\hline MAP3K4 & $G 1366 R$ & 6 & $\begin{array}{l}\text { endometrial carcinoma (4) } \\
\text { colon carcinoma (4) } \\
\text { glioma (3) } \\
\text { acute myeloid leukaemia (2) } \\
\text { medulloblastoma (1) }\end{array}$ \\
\hline MAX & & &
\end{tabular}




\section{References}

1. Breslow N, Olshan A, Beckwith JB, Green DM. Epidemiology of Wilms tumor. Med Pediatr Oncol [Internet]. 1993 Jan [cited 2016 Jan 27];21(3):17281. Available from: http://www.ncbi.nlm.nih.gov/pubmed/7680412

2. Rivera MN, Haber DA. Wilms' tumour: connecting tumorigenesis and organ development in the kidney. Nat Rev Cancer [Internet]. Nature Publishing Group; 2005 Sep 19 [cited 2018 Jan 30];5(9):699-712. Available from: http://www.nature.com/articles/nrc1696

3. Ma X, Liu Y, Liu Y, Alexandrov LB, Edmonson MN, Gawad C, et al. Pancancer genome and transcriptome analyses of 1,699 paediatric leukaemias and solid tumours. Nature [Internet]. Nature Publishing Group; 2018 Feb 28 [cited 2018 Apr 6];555(7696):371-6. Available from: http://www.nature.com/doifinder/10.1038/nature25795

4. Alexandrov LB, Nik-Zainal S, Wedge DC, Aparicio SAJR, Behjati S, Biankin A V, et al. Signatures of mutational processes in human cancer. Nature [Internet]. Europe PMC Funders; 2013 Aug 22 [cited 2018 Apr 6];500(7463):415-21. Available from: http://www.ncbi.nlm.nih.gov/pubmed/23945592

5. Torrezan GT, Ferreira EN, Nakahata AM, Barros BDF, Castro MTM, Correa $\mathrm{BR}$, et al. Recurrent somatic mutation in DROSHA induces microRNA profile changes in Wilms tumour. Nat Commun [Internet]. 2014 [cited 2016 Aug 5];5:4039. Available from: http://www.ncbi.nlm.nih.gov/pubmed/24909261

6. Rakheja D, Chen KS, Liu Y, Shukla AA, Schmid V, Chang T-C, et al. Somatic mutations in DROSHA and DICER1 impair microRNA biogenesis through distinct mechanisms in Wilms tumours. Nat Commun [Internet]. Nature Publishing Group; 2014 Jan 5 [cited 2015 Dec 13];2:4802. Available from: http://www.nature.com/ncomms/2014/140905/ncomms5802/abs/ncomms5802. html

7. Walz AL, Ooms A, Gadd S, Gerhard DS, Smith MA, Guidry Auvil JM, et al. Recurrent DGCR8, DROSHA, and SIX homeodomain mutations in favorable histology Wilms tumors. Cancer Cell [Internet]. 2015 Feb 9 [cited 2015 Dec 13];27(2):286-97. Available from: http://www.sciencedirect.com/science/article/pii/S1535610815000185

8. Wegert J, Ishaque N, Vardapour R, Geörg C, Gu Z, Bieg M, et al. Mutations in the SIX1/2 pathway and the DROSHA/DGCR8 miRNA microprocessor complex underlie high-risk blastemal type Wilms tumors. Cancer Cell [Internet]. 2015 Feb 9 [cited 2015 Dec 9];27(2):298-311. Available from: http://www.ncbi.nlm.nih.gov/pubmed/25670083

9. Gadd S, Huff V, Walz AL, Ooms AHAG, Armstrong AE, Gerhard DS, et al. A Children's Oncology Group and TARGET initiative exploring the genetic landscape of Wilms tumor. Nat Genet [Internet]. Nature Publishing Group; 2017 Aug 21 [cited 2018 Jan 30];49(10):1487-94. Available from: http://www.nature.com/doifinder/10.1038/ng.3940

10. Breslow N, Beck JB, Gol M, Sharpies K. Age Distribution of Wilms' Tumor: Report from the National Wilms' Tumor Study1. CANCER Res [Internet]. 1988 [cited 2018 Mar 16];48:1653-7. Available from: http://cancerres.aacrjournals.org/content/canres/48/6/1653.full.pdf

11. Scott RH, Stiller CA, Walker L, Rahman N. Syndromes and constitutional chromosomal abnormalities associated with Wilms tumour. J Med Genet 
[Internet]. 2006 Apr 5 [cited 2018 Feb 20];43(9):705-15. Available from: http://www.ncbi.nlm.nih.gov/pubmed/16690728

12. Ruteshouser EC, Huff V. Familial Wilms tumor. Am J Med Genet [Internet]. 2004 Aug 15 [cited 2018 Jan 30];129C(1):29-34. Available from: http://www.ncbi.nlm.nih.gov/pubmed/15264270

13. Segers H, van den Heuvel-Eibrink MM, Pritchard-Jones K, Coppes MJ, Aitchison M, Bergeron C, et al. Management of adults with Wilms' tumor: recommendations based on international consensus. Expert Rev Anticancer Ther [Internet]. 2011 Jul [cited 2016 Feb 25];11(7):1105-13. Available from: http://www.ncbi.nlm.nih.gov/pubmed/21806333

14. Nakata K, Ito Y, Magadi W, Bonaventure A, Stiller CA, Katanoda K, et al. Childhood cancer incidence and survival in Japan and England: A populationbased study (1993-2010). Cancer Sci [Internet]. 2018 Feb [cited 2018 May 18];109(2):422-34. Available from: http://www.ncbi.nlm.nih.gov/pubmed/29178401

15. Stiller CA, Parkin DM. International variations in the incidence of childhood renal tumours. Br J Cancer [Internet]. 1990 Dec [cited 2018 Feb 23];62(6):1026-30. Available from: http://www.ncbi.nlm.nih.gov/pubmed/2175212

16. Steliarova-Foucher E, Colombet M, Ries LAG, Moreno F, Dolya A, Bray F, et al. International incidence of childhood cancer, 2001-10: a population-based registry study. Lancet Oncol [Internet]. Elsevier; 2017 Jun 1 [cited 2018 May 18];18(6):719-31. Available from:

http://www.ncbi.nlm.nih.gov/pubmed/28410997

17. Wright KD, Green DM, Daw NC. Late effects of treatment for wilms tumor. Pediatr Hematol Oncol [Internet]. 2009 Sep [cited 2016 Feb 25];26(6):407-13. Available from:

http://www.pubmedcentral.nih.gov/articlerender.fcgi?artid=2829307\&tool=pm centrez\&rendertype $=$ abstract

18. Spreafico F, Pritchard Jones K, Malogolowkin MH, Bergeron C, Hale J, de Kraker J, et al. Treatment of relapsed Wilms tumors: lessons learned. Expert Rev Anticancer Ther [Internet]. Taylor \& Francis; 2009 Dec 10 [cited 2018 Feb 23];9(12):1807-15. Available from: http://www.tandfonline.com/doi/full/10.1586/era.09.159

19. Paintsil V, David H, Kambugu J, Renner L, Kouya F, Eden T, et al. The Collaborative Wilms Tumour Africa Project; baseline evaluation of Wilms tumour treatment and outcome in eight institutes in sub-Saharan Africa. Eur J Cancer [Internet]. 2015 Jan [cited 2016 Apr 12];51(1):84-91. Available from: http://www.ncbi.nlm.nih.gov/pubmed/25465189

20. van den Heuvel-Eibrink MM, Hol JA, Pritchard-Jones K, van Tinteren H, Furtwängler R, Verschuur AC, et al. Position paper: Rationale for the treatment of Wilms tumour in the UMBRELLA SIOP-RTSG 2016 protocol. Nat Rev Urol [Internet]. Nature Publishing Group; 2017 Oct 31 [cited 2018 Jan 29];14(12):743-52. Available from: http://www.nature.com/doifinder/10.1038/nrurol.2017.163

21. Graf N, Tournade M-F, de Kraker J. THE ROLE OF PREOPERATIVE CHEMOTHERAPY IN THE MANAGEMENT OF WILMS' TUMOR: The SIOP Studies. Urol Clin North Am [Internet]. Elsevier; 2000 Aug 1 [cited 2018 Feb 23];27(3):443-54. Available from: https://www.sciencedirect.com/science/article/pii/S0094014305700926 
22. Irtan S, Jitlal M, Bate J, Powis M, Vujanic G, Kelsey A, et al. Risk factors for local recurrence in Wilms tumour and the potential influence of biopsy - The United Kingdom experience. Eur J Cancer. 2015;51(2):225-32.

23. Krepischi AC V, Maschietto M, Ferreira EN, Silva AG, Costa SS, Da Cunha IW, et al. Genomic imbalances pinpoint potential oncogenes and tumor suppressors in Wilms tumors. [cited 2018 May 18]; Available from: https://molecularcytogenetics.biomedcentral.com/track/pdf/10.1186/s13039016-0227-y

24. Grundy PE, Breslow NE, Li S, Perlman E, Beckwith JB, Ritchey ML, et al. Loss of Heterozygosity for Chromosomes $1 p$ and 16q Is an Adverse Prognostic Factor in Favorable-Histology Wilms Tumor: A Report From the National Wilms Tumor Study Group. J Clin Oncol [Internet]. 2005 Oct 10 [cited 2018 Jan 29];23(29):7312-21. Available from: http://www.ncbi.nlm.nih.gov/pubmed/16129848

25. Fernandez C V., Perlman EJ, Mullen EA, Chi Y-Y, Hamilton TE, Gow KW, et al. Clinical Outcome and Biological Predictors of Relapse After Nephrectomy Only for Very Low-risk Wilms Tumor. Ann Surg [Internet]. 2017 Apr [cited 2018 Jan 29];265(4):835-40. Available from: http://www.ncbi.nlm.nih.gov/pubmed/27811504

26. Brok J, Treger TD, Gooskens SL, van den Heuvel-Eibrink MM, PritchardJones K. Biology and treatment of renal tumours in childhood. Eur J Cancer [Internet]. Elsevier; 2016 Nov 1 [cited 2018 May 18];68:179-95. Available from: http://linkinghub.elsevier.com/retrieve/pii/S0959804916324261

27. Dome JS, Graf N, Geller JI, Fernandez C V, Mullen EA, Spreafico F, et al. Advances in Wilms Tumor Treatment and Biology: Progress Through International Collaboration. J Clin Oncol [Internet]. American Society of Clinical Oncology; 2015 Sep 20 [cited 2018 Apr 9];33(27):2999-3007. Available from: http://ascopubs.org/doi/10.1200/JCO.2015.62.1888

28. Ha TC, Spreafico F, Graf N, Dallorso S, Dome JS, Malogolowkin M, et al. An international strategy to determine the role of high dose therapy in recurrent Wilms' tumour. Eur J Cancer [Internet]. 2013 Jan [cited 2016 Jun 20];49(1):194-210. Available from:

http://www.ncbi.nlm.nih.gov/pubmed/22959164

29. Furtwängler R, Nourkami N, Alkassar M, von Schweinitz D, Schenk J-P, Rübe $\mathrm{C}$, et al. Update on relapses in unilateral nephroblastoma registered in 3 consecutive SIOP/GPOH studies - a report from the GPOH-nephroblastoma study group. Klin Pädiatrie [Internet]. 2011 May [cited 2016 Jun 20];223(3):113-9. Available from: http://www.ncbi.nlm.nih.gov/pubmed/21509706

30. Malogolowkin M, Cotton CA, Green DM, Breslow NE, Perlman E, Miser J, et al. Treatment of Wilms tumor relapsing after initial treatment with vincristine, actinomycin D, and doxorubicin. A report from the National Wilms Tumor Study Group. Pediatr Blood Cancer [Internet]. 2008 Feb [cited 2016 Apr 29];50(2):236-41. Available from: http://www.ncbi.nlm.nih.gov/pubmed/17539021

31. Green DM, Cotton CA, Malogolowkin M, Breslow NE, Perlman E, Miser J, et al. Treatment of Wilms tumor relapsing after initial treatment with vincristine and actinomycin D: a report from the National Wilms Tumor Study Group. Pediatr Blood Cancer [Internet]. 2007 May [cited 2016 Feb 9];48(5):493-9. Available from: http://www.ncbi.nlm.nih.gov/pubmed/16547940 
32. Green DM, Breslow NE, Beckwith JB, Ritchey ML, Shamberger RC, Haase GM, et al. Treatment With Nephrectomy Only for Small, Stage I/Favorable Histology Wilms' Tumor: A Report From the National Wilms' Tumor Study Group. J Clin Oncol [Internet]. 2001 Sep 1 [cited 2018 Jan 30];19(17):371924. Available from: http://www.ncbi.nlm.nih.gov/pubmed/11533093

33. Perlman EJ, Grundy PE, Anderson JR, Jennings LJ, Green DM, Dome JS, et al. WT1 mutation and 11P15 loss of heterozygosity predict relapse in very lowrisk wilms tumors treated with surgery alone: a children's oncology group study. J Clin Oncol [Internet]. 2011 Feb 20 [cited 2016 Apr 12];29(6):698-703. Available from: http://jco.ascopubs.org/content/29/6/698.full

34. Chagtai T, Zill C, Dainese L, Wegert J, Savola S, Popov S, et al. Gain of 1q As a Prognostic Biomarker in Wilms Tumors (WTs) Treated With Preoperative Chemotherapy in the International Society of Paediatric Oncology (SIOP) WT 2001 Trial: A SIOP Renal Tumours Biology Consortium Study. J Clin Oncol [Internet]. $2016 \mathrm{Jul} 18$ [cited $2016 \mathrm{Jul} 22$ ]; Available from: http://www.ncbi.nlm.nih.gov/pubmed/27432915

35. Gratias EJ, Dome JS, Jennings LJ, Chi Y-Y, Tian J, Anderson J, et al. Association of Chromosome 1q Gain With Inferior Survival in FavorableHistology Wilms Tumor: A Report From the Children's Oncology Group. J Clin Oncol [Internet]. 2016 Jul 11 [cited 2016 Aug 5]; Available from: http://www.ncbi.nlm.nih.gov/pubmed/27400937

36. Segers H, van den Heuvel-Eibrink MM, Williams RD, van Tinteren H, Vujanic $\mathrm{G}$, Pieters R, et al. Gain of 1q is a marker of poor prognosis in Wilms' tumors. Genes Chromosomes Cancer [Internet]. 2013 Nov [cited 2016 Jun 20];52(11):1065-74. Available from: http://www.ncbi.nlm.nih.gov/pubmed/24038759

37. Beckwith JB, Palmer NF. Histopathology and prognosis of Wilms tumors: results from the First National Wilms' Tumor Study. Cancer [Internet]. 1978 May [cited 2018 Jan 31];41(5):1937-48. Available from: http://www.ncbi.nlm.nih.gov/pubmed/206343

38. Bardeesy N, Falkoff D, Petruzzi MJ, Nowak N, Zabel B, Adam M, et al. Anaplastic Wilms' tumour, a subtype displaying poor prognosis, harbours p53 gene mutations. Nat Genet [Internet]. 1994 May [cited 2016 Jun 16];7(1):91-7. Available from: http://www.ncbi.nlm.nih.gov/pubmed/8075648

39. Maschietto M, Williams RD, Chagtai T, Popov SD, Sebire NJ, Vujanic G, et al. TP53 mutational status is a potential marker for risk stratification in Wilms tumour with diffuse anaplasia. PLoS One [Internet]. 2014 Jan [cited 2015 Dec 23];9(10):e109924. Available from: http://www.pubmedcentral.nih.gov/articlerender.fcgi?artid=4196953\&tool=pm centrez\&rendertype $=$ abstract

40. Ooms AHAG, Gadd S, Gerhard DS, Smith MA, Guidry Auvil JM, Meerzaman D, et al. Significance of TP53 Mutation in Wilms Tumors with Diffuse Anaplasia: A Report from the Children's Oncology Group. Clin Cancer Res [Internet]. 2016 Oct 4 [cited 2016 Nov 9]; Available from: http://clincancerres.aacrjournals.org/cgi/doi/10.1158/1078-0432.CCR-16-0985

41. Wegert J, Vokuhl C, Ziegler B, Ernestus K, Leuschner I, Furtwängler R, et al. TP53 alterations in Wilms tumour represent progression events with strong intratumour heterogeneity that are closely linked but not limited to anaplasia. J Pathol Clin Res [Internet]. Wiley-Blackwell; 2017 Oct [cited 2018 Jan 31];3(4):234-48. Available from: 
http://www.ncbi.nlm.nih.gov/pubmed/29085664

42. Charles A. Stiller and Andrew F. Olshan, Epidemiology of Renal Tumours of Childhood; Renal Tumors of Childhood - Biology and Therapy;Kathy Prithcard-Jones and Jeff Dome; Springer http://www.springer.com/us/book/9783662440025 (accessed March 14, 2016).

43. Charlton J, Irtan S, Bergeron C, Pritchard-Jones K. Bilateral Wilms tumour: a review of clinical and molecular features. Expert Rev Mol Med [Internet]. Cambridge University Press; 2017 Jul 18 [cited 2018 Feb 1];19:e8. Available from: http://www.ncbi.nlm.nih.gov/pubmed/28716159

44. Termuhlen AM, Tersak JM, Liu Q, Yasui Y, Stovall M, Weathers R, et al. Twenty-five year follow-up of childhood Wilms tumor: a report from the Childhood Cancer Survivor Study. Pediatr Blood Cancer [Internet]. 2011 Dec 15 [cited 2016 Feb 25];57(7):1210-6. Available from:

http://www.pubmedcentral.nih.gov/articlerender.fcgi? artid=4634648\&tool=pm centrez\&rendertype $=$ abstract

45. Breslow NE, Collins AJ, Ritchey ML, Grigoriev YA, Peterson SM, Green DM. End stage renal disease in patients with Wilms tumor: results from the National Wilms Tumor Study Group and the United States Renal Data System. J Urol [Internet]. 2005 Nov [cited 2016 Jun 17];174(5):1972-5. Available from: http://www.ncbi.nlm.nih.gov/pubmed/16217371

46. Green DM, Grigoriev YA, Nan B, Takashima JR, Norkool PA, D'Angio GJ, et al. Congestive heart failure after treatment for Wilms' tumor: a report from the National Wilms' Tumor Study group. J Clin Oncol [Internet]. 2001 Apr 1 [cited 2016 Feb 11];19(7):1926-34. Available from: http://www.ncbi.nlm.nih.gov/pubmed/11283124

47. Pritchard-Jones K, Bergeron C, de Camargo B, van den Heuvel-Eibrink MM, Acha T, Godzinski J, et al. Omission of doxorubicin from the treatment of stage II-III, intermediate-risk Wilms' tumour (SIOP WT 2001): an open-label, non-inferiority, randomised controlled trial. Lancet (London, England) [Internet]. Elsevier; 2015 Sep 19 [cited 2016 Feb 25];386(9999):1156-64. Available from: http://www.thelancet.com/article/S0140673614623953/fulltext

48. Dix DB, Gratias EJ, Seibel N, Anderson JR, Mullen EA, Geller JI, et al. Omission of lung radiation in patients with stage IV favorable histology Wilms Tumor (FHWT) showing complete lung nodule response after chemotherapy: A report from Children's Oncology Group study AREN0533. ASCO Meet Abstr [Internet]. 2015 May 20 [cited 2016 May 17];33(15_suppl):10011. Available from: http://hwmaint.meeting.ascopubs.org/cgi/content/abstract/33/15_suppl/10011

49. Magrath I, Steliarova-Foucher E, Epelman S, Ribeiro RC, Harif M, Li C-K, et al. Paediatric cancer in low-income and middle-income countries. Lancet Oncol [Internet]. Elsevier; 2013 Mar 1 [cited 2016 Feb 20];14(3):e104-16. Available from: http://www.thelancet.com/article/S1470204513700081/fulltext

50. Gatta G, Botta L, Rossi S, Aareleid T, Bielska-Lasota M, Clavel J, et al. Childhood cancer survival in Europe 1999-2007: results of EUROCARE-5--a population-based study. Lancet Oncol [Internet]. Elsevier; 2014 Jan 1 [cited 2016 Feb 23];15(1):35-47. Available from: http://www.thelancet.com/article/S1470204513705485/fulltext

51. Njuguna F, Martijn HA, Kuremu RT, Saula P, Kirtika P, Olbara G, et al. Wilms Tumor Treatment Outcomes: Perspectives From a Low-Income Setting. J Glob Oncol [Internet]. American Society of Clinical Oncology; 2017 Oct 
[cited 2018 Feb 4];3(5):555-62. Available from: http://www.ncbi.nlm.nih.gov/pubmed/29094095

52. Israels T, Borgstein E, Pidini D, Chagaluka G, de Kraker J, Kamiza S, et al. Management of children with a Wilms tumor in Malawi, sub-Saharan Africa. J Pediatr Hematol Oncol [Internet]. 2012 Nov [cited 2016 Apr 12];34(8):606-10. Available from: http://www.ncbi.nlm.nih.gov/pubmed/22767130

53. Vainio S, Lin Y. Organogenesis: Coordinating early kidney development: lessons from gene targeting. Nat Rev Genet [Internet]. Nature Publishing Group; 2002 Jul 1 [cited 2018 Mar 11];3(7):533-43. Available from: http://www.nature.com/doifinder/10.1038/nrg842

54. Li C-M, Guo M, Borczuk A, Powell CA, Wei M, Thaker HM, et al. Gene Expression in Wilms' Tumor Mimics the Earliest Committed Stage in the Metanephric Mesenchymal-Epithelial Transition. Am J Pathol [Internet]. 2002 Jun [cited 2018 Mar 11];160(6):2181-90. Available from: http://www.ncbi.nlm.nih.gov/pubmed/12057921

55. Fukuzawa R, Anaka MR, Morison IM, Reeve AE. The developmental programme for genesis of the entire kidney is recapitulated in Wilms tumour. Long D, editor. PLoS One [Internet]. Public Library of Science; 2017 Oct 17 [cited 2018 Mar 11];12(10):e0186333. Available from:

http://dx.plos.org/10.1371/journal.pone.0186333

56. Merks JHM, Caron HN, Hennekam RCM. High incidence of malformation syndromes in a series of 1,073 children with cancer. Am J Med Genet Part A [Internet]. 2005 Apr 15 [cited 2018 Feb 20];134A(2):132-43. Available from: http://www.ncbi.nlm.nih.gov/pubmed/15712196

57. Dumoucel S, Gauthier-Villars M, Stoppa-Lyonnet D, Parisot P, Brisse H, Philippe-Chomette P, et al. Malformations, genetic abnormalities, and Wilms tumor. Pediatr Blood Cancer [Internet]. 2014 Jan [cited 2016 Feb 25];61(1):140-4. Available from: http://www.ncbi.nlm.nih.gov/pubmed/23970395

58. Pelletier J, Bruening W, Li FP, Haber DA, Glaser T, Housman DE. WT1 mutations contribute to abnormal genital system development and hereditary Wilms' tumour. Nature [Internet]. 1991 Oct 3 [cited 2015 Nov 13];353(6343):431-4. Available from: http://www.ncbi.nlm.nih.gov/pubmed/1654525

59. Pritchard-Jones K, Fleming S, Davidson D, Bickmore W, Porteous D, Gosden $\mathrm{C}$, et al. The candidate Wilms' tumour gene is involved in genitourinary development. Nature [Internet]. 1990 Jul 12 [cited 2015 Dec 24];346(6280):194-7. Available from: http://www.ncbi.nlm.nih.gov/pubmed/2164159

60. Lee SB, Haber DA. Wilms Tumor and the WT1 Gene. Exp Cell Res [Internet]. 2001 Mar 10 [cited 2018 May 20];264(1):74-99. Available from: http://www.ncbi.nlm.nih.gov/pubmed/11237525

61. Kreidberg JA, Sariola H, Loring JM, Maeda M, Pelletier J, Housman D, et al. WT-1 is required for early kidney development. Cell [Internet]. 1993 Aug 27 [cited 2015 Dec 20];74(4):679-91. Available from: http://www.ncbi.nlm.nih.gov/pubmed/8395349

62. Hu Q, Gao F, Tian W, Ruteshouser EC, Wang Y, Lazar A, et al. Wt1 ablation and Igf2 upregulation in mice result in Wilms tumors with elevated ERK1/2 phosphorylation. J Clin Invest [Internet]. American Society for Clinical Investigation; 2011 Jan 4 [cited 2015 Dec 7];121(1):174-83. Available from: 
http://www.jci.org/articles/view/43772

63. Hartwig S, Ho J, Pandey P, Macisaac K, Taglienti M, Xiang M, et al. Genomic characterization of Wilms' tumor suppressor 1 targets in nephron progenitor cells during kidney development. Development [Internet]. Oxford University Press for The Company of Biologists Limited; 2010 Apr 1 [cited 2018 Mar 12];137(7):1189-203. Available from: http://www.ncbi.nlm.nih.gov/pubmed/20215353

64. Breslow NE, Norris R, Norkool PA, Kang T, Beckwith JB, Perlman EJ, et al. Characteristics and outcomes of children with the Wilms tumor-Aniridia syndrome: a report from the National Wilms Tumor Study Group. J Clin Oncol [Internet]. American Society of Clinical Oncology; 2003 Dec 15 [cited 2018 Feb 24];21(24):4579-85. Available from: http://ascopubs.org/doi/10.1200/JCO.2003.06.096

65. Mueller RF. The Denys-Drash syndrome. J Med Genet [Internet]. BMJ Publishing Group; 1994 Jun [cited 2018 Feb 24];31(6):471-7. Available from: http://www.ncbi.nlm.nih.gov/pubmed/8071974

66. Pelletier J, Bruening W, Kashtan CE, Mauer SM, Manivel JC, Striegel JE, et al. Germline mutations in the Wilms' tumor suppressor gene are associated with abnormal urogenital development in Denys-Drash syndrome. Cell [Internet]. 1991 Oct 18 [cited 2015 Dec 24];67(2):437-47. Available from: http://www.ncbi.nlm.nih.gov/pubmed/1655284

67. Barbaux S, Niaudet P, Gubler M-C, Grünfeld J-P, Jaubert F, Kuttenn F, et al. Donor splice-site mutations in WT1 are responsible for Frasier syndrome. Nat Genet [Internet]. 1997 Dec 1 [cited 2018 Feb 24];17(4):467-70. Available from: http://www.ncbi.nlm.nih.gov/pubmed/9398852

68. Park S, Bernard A, Bove KE, Sens DA, Hazen-Martin DJ, Garvin AJ, et al. Inactivation of WT1 in nephrogenic rests, genetic precursors to Wilms' tumour. Nat Genet [Internet]. 1993 Dec [cited 2015 Dec 24];5(4):363-7. Available from: http://dx.doi.org/10.1038/ng1293-363

69. Scott RH, Murray A, Baskcomb L, Turnbull C, Loveday C, Al-Saadi R, et al. Stratification of Wilms tumor by genetic and epigenetic analysis. Oncotarget [Internet]. 2012 Mar [cited 2015 Dec 23];3(3):327-35. Available from: http://www.pubmedcentral.nih.gov/articlerender.fcgi?artid=3359888\&tool=pm centrez\&rendertype $=$ abstract

70. Cresswell GD, Apps JR, Chagtai T, Mifsud B, Bentley CC, Maschietto M, et al. Intra-Tumor Genetic Heterogeneity in Wilms Tumor: Clonal Evolution and Clinical Implications. EBioMedicine [Internet]. Elsevier; 2016 May [cited 2016 Jul 15];0(0):991-1000. Available from:

http://linkinghub.elsevier.com/retrieve/pii/S2352396416302213

71. Charles AK, Brown KW, Berry PJ. Microdissecting the Genetic Events in Nephrogenic Rests and Wilms' Tumor Development. Am J Pathol [Internet]. 1998 Sep [cited 2018 Feb 16];153(3):991-1000. Available from: http://www.ncbi.nlm.nih.gov/pubmed/9736048

72. Cooper WN, Luharia A, Evans GA, Raza H, Haire AC, Grundy R, et al. Molecular subtypes and phenotypic expression of Beckwith-Wiedemann syndrome. Eur J Hum Genet [Internet]. Nature Publishing Group; 2005 Sep 6 [cited 2018 Mar 2];13(9):1025-32. Available from:

http://www.nature.com/articles/5201463

73. Pilia G, Hughes-Benzie RM, MacKenzie A, Baybayan P, Chen EY, Huber R, et al. Mutations in GPC3, a glypican gene, cause the Simpson-Golabi-Behmel 
overgrowth syndrome. Nat Genet [Internet]. 1996 Mar 1 [cited 2018 Feb 24];12(3):241-7. Available from:

http://www.ncbi.nlm.nih.gov/pubmed/8589713

74. Astuti D, Morris MR, Cooper WN, Staals RHJ, Wake NC, Fews GA, et al. Germline mutations in DIS3L2 cause the Perlman syndrome of overgrowth and Wilms tumor susceptibility. Nat Genet [Internet]. Nature Publishing Group, a division of Macmillan Publishers Limited. All Rights Reserved.; 2012 Mar [cited 2015 Dec 13];44(3):277-84. Available from:

http://dx.doi.org/10.1038/ng.1071

75. Palculict TB, Ruteshouser EC, Fan Y, Wang W, Strong L, Huff V. Identification of germline DICER1 mutations and loss of heterozygosity in familial Wilms tumour. J Med Genet [Internet]. NIH Public Access; 2016 [cited 2018 Feb 24];53(6):385-8. Available from: http://www.ncbi.nlm.nih.gov/pubmed/26566882

76. Rahman N, Arbour L, Tonin P, Renshaw J, Pelletier J, Baruchel S, et al. Evidence for a familial Wilms' tumour gene (FWT1) on chromosome 17q12q21. Nat Genet [Internet]. 1996 Aug 1 [cited 2018 Feb 24];13(4):461-3. Available from: http://www.ncbi.nlm.nih.gov/pubmed/8696342

77. McDonald JM, Douglass EC, Fisher R, Geiser CF, Krill CE, Strong LC, et al. Linkage of familial Wilms' tumor predisposition to chromosome 19 and a twolocus model for the etiology of familial tumors. Cancer Res [Internet]. 1998 Apr 1 [cited 2018 Feb 24];58(7):1387-90. Available from: http://www.ncbi.nlm.nih.gov/pubmed/9537236

78. Koesters R, Ridder R, Kopp-Schneider A, Betts D, Adams V, Niggli F, et al. Mutational Activation of the \{beta\}-Catenin Proto-Oncogene Is a Common Event in the Development of Wilms' Tumors. Cancer Res [Internet]. 1999 Aug 1 [cited 2015 Dec 24];59(16):3880-2. Available from: http://cancerres.aacrjournals.org/content/59/16/3880.abstract?ijkey=56688a7bb c206cbe85eda88fc68e36aed6199d2b\&keytype2=tf_ipsecsha

79. Rivera MN, Kim WJ, Wells J, Driscoll DR, Brannigan BW, Han M, et al. An X chromosome gene, WTX, is commonly inactivated in Wilms tumor. Science [Internet]. 2007 Feb 2 [cited 2016 Jun 16];315(5812):642-5. Available from: http://www.ncbi.nlm.nih.gov/pubmed/17204608

80. Williams RD, Chagtai T, Alcaide-German M, Apps J, Wegert J, Popov S, et al. Multiple mechanisms of MYCN dysregulation in Wilms tumour. Oncotarget [Internet]. 2015 Mar 30 [cited 2015 Dec 24];6(9):7232-43. Available from: http://www.pubmedcentral.nih.gov/articlerender.fcgi?artid=4466681\&tool=pm centrez\&rendertype $=$ abstract

81. Beltran H. The N-myc Oncogene: Maximizing its Targets, Regulation, and Therapeutic Potential. Mol Cancer Res [Internet]. 2014 Jun [cited 2016 Feb 25];12(6):815-22. Available from:

http://www.ncbi.nlm.nih.gov/pubmed/24589438

82. Kusafuka T, Miao J, Kuroda S, Udatsu Y, Yoneda A. Codon 45 of the betacatenin gene, a specific mutational target site of Wilms' tumor. Int J Mol Med [Internet]. 2002 Oct [cited 2018 May 19];10(4):395-9. Available from: http://www.ncbi.nlm.nih.gov/pubmed/12239584

83. Amit S, Hatzubai A, Birman Y, Andersen JS, Ben-Shushan E, Mann M, et al. Axin-mediated CKI phosphorylation of beta-catenin at Ser 45: a molecular switch for the Wnt pathway. Genes Dev [Internet]. Cold Spring Harbor Laboratory Press; 2002 May 1 [cited 2018 May 19];16(9):1066-76. Available 
from: http://www.ncbi.nlm.nih.gov/pubmed/12000790

84. Perlman EJ, Gadd S, Arold ST, Radhakrishnan A, Gerhard DS, Jennings L, et al. MLLT1 YEATS domain mutations in clinically distinctive Favourable Histology Wilms tumours. Nat Commun [Internet]. 2015 [cited 2016 Jun 16];6:10013. Available from: http://www.ncbi.nlm.nih.gov/pubmed/26635203

85. Parsons DW, Li M, Zhang X, Jones S, Leary RJ, Lin JC-H, et al. The genetic landscape of the childhood cancer medulloblastoma. Science [Internet]. 2011 Jan 28 [cited 2015 Nov 27];331(6016):435-9. Available from: http://www.pubmedcentral.nih.gov/articlerender.fcgi?artid=3110744\&tool=pm centrez\&rendertype $=$ abstract

86. Hasselblatt M, Gesk S, Oyen F, Rossi S, Viscardi E, Giangaspero F, et al. Nonsense mutation and inactivation of SMARCA4 (BRG1) in an atypical teratoid/rhabdoid tumor showing retained SMARCB1 (INI1) expression. Am J Surg Pathol [Internet]. 2011/05/14. 2011;35(6):933-5. Available from: http://www.ncbi.nlm.nih.gov/pubmed/21566516

87. Rakheja D, Chen KS, Liu Y, Shukla AA, Schmid V, Chang T-C, et al. Somatic mutations in DROSHA and DICER1 impair microRNA biogenesis through distinct mechanisms in Wilms tumours. Nat Commun [Internet]. 2014 Jan [cited 2015 Dec 13];2:4802. Available from:

http://www.pubmedcentral.nih.gov/articlerender.fcgi?artid=4159681\&tool=pm centrez\&rendertype $=$ abstract

88. Walz AL, Ooms A, Gadd S, Gerhard DS, Smith MA, Guidry Auvil JM, et al. Recurrent DGCR8, DROSHA, and SIX homeodomain mutations in favorable histology Wilms tumors. Cancer Cell [Internet]. 2015 Feb 9 [cited 2015 Dec 13];27(2):286-97. Available from: http://www.ncbi.nlm.nih.gov/pubmed/25670082

89. Huynh KD, Fischle W, Verdin E, Bardwell VJ. BCoR, a novel corepressor involved in BCL-6 repression. Genes Dev [Internet]. 2000 Jul 15 [cited 2018 Mar 9];14(14):1810-23. Available from: http://www.ncbi.nlm.nih.gov/pubmed/10898795

90. Pagan JK, Arnold J, Hanchard KJ, Kumar R, Bruno T, Jones MJK, et al. A Novel Corepressor, BCoR-L1, Represses Transcription through an Interaction with CtBP. J Biol Chem [Internet]. 2007 May 18 [cited 2018 Mar 9];282(20):15248-57. Available from: http://www.ncbi.nlm.nih.gov/pubmed/17379597

91. Yamamoto Y, Abe A, Emi N. Clarifying the Impact of Polycomb Complex Component Disruption in Human Cancers. Mol Cancer Res [Internet]. 2014 Apr [cited 2018 Mar 9];12(4):479-84. Available from:

http://www.ncbi.nlm.nih.gov/pubmed/24515802

92. Roy A, Kumar V, Zorman B, Fang E, Haines KM, Doddapaneni H, et al. Recurrent internal tandem duplications of BCOR in clear cell sarcoma of the kidney. Nat Commun [Internet]. 2015 [cited 2016 Jun 16];6:8891. Available from: http://www.ncbi.nlm.nih.gov/pubmed/26573325

93. Liu PY, Erriquez D, Marshall GM, Tee AE, Polly P, Wong M, et al. Effects of a Novel Long Noncoding RNA, lncUSMycN, on N-Myc Expression and Neuroblastoma Progression. 2014 [cited 2018 Feb 15];106(113). Available from:

https://watermark.silverchair.com/dju113.pdf?token=AQECAHi208BE49Ooan 9kkhW_Ercy7Dm3ZL_9Cf3qfKAc485ysgAAAakwggGlBgkqhkiG9w0BBwag ggGWMIIBkgIBADCCAYsGCSqGSIb3DQEHATAeBglghkgBZQMEAS4wE 
QQMu5AAaq7jsv8OVvtOAgEQgIIBXDk8owqzmowqnVQgiKy4QmpmvZlw 6-

TgfdAO1Sk3Y03VS5arzwGfp63Eegz4GZHzfegNT17ULaWytgqixQXLfS7IiU UTjLmvEe8KZ9b80roN6DHYi-hcKhoUCaYMiZWsC6mUWugh93V9WnIghh9uopi9J6XHmSjbqDajiL1yeCzWiV9izrBw7pSAdcyOyym_bgw dL112RjwiYAfqoAEL3Qrd15UiGlcDDPbsE9lotPG5VlarmQyNYFSxVbMM YKKS3gl620avu1z3MmbLpbqxMSAoPBkoo3UtQ60vPh2XxrnjqLjMX1Wgy2 HQ2rfUiXC37E2A6XvdvH9rTpF355ICURmBPU357mrK119BX3MFJRdJqS XVwE3YwASXrTU5yr1M10iDD5T013I-mtppFkX3b76F-

RwXEQWGKiqNJva8dr1VGjoSRfR_GJRwc_1CRIq3QaUCOlI2BzNaevAhA

94. Cascon A, Robledo M. MAX and MYC: A Heritable Breakup. Cancer Res [Internet]. 2012 Jul 1 [cited 2018 Feb 15];72(13):3119-24. Available from: http://www.ncbi.nlm.nih.gov/pubmed/22706201

95. Ferrucci F, Ciaccio R, Monticelli S, Pigini P, di Giacomo S, Purgato S, et al. MAX to MYCN intracellular ratio drives the aggressive phenotype and clinical outcome of high risk neuroblastoma. Biochim Biophys Acta - Gene Regul Mech [Internet]. Elsevier; 2018 Feb 3 [cited 2018 Feb 15]; Available from: https://www.sciencedirect.com/science/article/pii/S1874939917302894?via\%3 Dihub

96. Xu B, Zeng D, Wu Y, Zheng R, Gu L, Lin X, et al. Tumor suppressor menin represses paired box gene 2 expression via Wilms tumor suppressor proteinpolycomb group complex. J Biol Chem [Internet]. 2011 Apr 22 [cited 2015 Dec 25];286(16):13937-44. Available from: http://www.jbc.org/content/286/16/13937.abstract?ijkey=eb8aeff2b60725719c 85178516dd953f83e6f97c\&keytype2=tf_ipsecsha

97. Mengelbier LH, Karlsson J, Lindgren D, Valind A, Lilljebjörn H, Jansson C, et al. Intratumoral genome diversity parallels progression and predicts outcome in pediatric cancer. Nat Commun [Internet]. Nature Publishing Group; 2015 Jan 27 [cited 2015 Nov 21];6:6125. Available from: http://www.nature.com/ncomms/2015/150127/ncomms7125/abs/ncomms7125. html

98. Williams RD, Al-Saadi R, Natrajan R, Mackay A, Chagtai T, Little S, et al. Molecular profiling reveals frequent gain of MYCN and anaplasia-specific loss of $4 \mathrm{q}$ and 14q in wilms tumor. Genes, Chromosom Cancer [Internet]. $2011 \mathrm{Dec}$ [cited 2018 Feb 17];50(12):982-95. Available from:

http://www.ncbi.nlm.nih.gov/pubmed/21882282

99. Cole BL, Pritchard CC, Anderson M, Leary SE. Targeted Sequencing of Malignant Supratentorial Pediatric Brain Tumors Demonstrates a High Frequency of Clinically Relevant Mutations. Pediatr Dev Pathol [Internet]. 2017 Nov 27 [cited 2018 Feb 19];109352661774390. Available from: http://www.ncbi.nlm.nih.gov/pubmed/29173061

100. Southey MC, Goldgar DE, Winqvist R, Pylkäs K, Couch F, Tischkowitz M, et al. PALB2, CHEK2 and ATM rare variants and cancer risk: data from COGS. J Med Genet [Internet]. BMJ Publishing Group Ltd; 2016 Sep 5 [cited 2018 Feb 19];53(12):800-11. Available from: http://www.ncbi.nlm.nih.gov/pubmed/27595995

101. Reid S, Schindler D, Hanenberg H, Barker K, Hanks S, Kalb R, et al. Biallelic mutations in PALB2 cause Fanconi anemia subtype FA-N and predispose to childhood cancer. Nat Genet [Internet]. Nature Publishing Group; 2007 Feb [cited 2018 Feb 19];39(2):162-4. Available from: 
http://www.nature.com/articles/ng1947

102. Mahamdallie SS, Hanks S, Karlin KL, Zachariou A, R Perdeaux E, Ruark E, et al. Mutations in the transcriptional repressor REST predispose to Wilms tumor. Nat Genet [Internet]. Nature Publishing Group, a division of Macmillan Publishers Limited. All Rights Reserved.; 2015 Nov 9 [cited 2015 Dec 1];47(12):1471-4. Available from: http://dx.doi.org/10.1038/ng.3440

103. Gopalakrishnan V. REST and the RESTless: in stem cells and beyond. Future Neurol [Internet]. 2009 Jan [cited 2016 Apr 12];4(3):317-29. Available from: http://www.pubmedcentral.nih.gov/articlerender.fcgi?artid=2719900\&tool=pm centrez\&rendertype $=$ abstract

104. Hanks S, Perdeaux ER, Seal S, Ruark E, Mahamdallie SS, Murray A, et al. Germline mutations in the PAF1 complex gene CTR9 predispose to Wilms tumour. Nat Commun [Internet]. Nature Publishing Group; 2014 Aug 7 [cited 2018 Feb 19];5:4398. Available from: http://www.nature.com/doifinder/10.1038/ncomms5398

105. Martins AG, Pinto AT, Domingues R, Cavaco BM. Identification of a novel CTR9 germline mutation in a family with Wilms tumor. Eur J Med Genet [Internet]. Elsevier Masson; 2017 Dec 29 [cited 2018 Feb 19]; Available from: https://www.sciencedirect.com/science/article/pii/S1769721217305906?via\%3 Dihub

106. Yost S, de Wolf B, Hanks S, Zachariou A, Marcozzi C, Clarke M, et al. Biallelic TRIP13 mutations predispose to Wilms tumor and chromosome missegregation. Nat Genet [Internet]. Nature Publishing Group; 2017 May 29 [cited 2018 Feb 20];49(7):1148-51. Available from: http://www.nature.com/doifinder/10.1038/ng.3883

107. Urbach A, Yermalovich A, Zhang J, Spina CS, Zhu H, Perez-Atayde AR, et al. Lin28 sustains early renal progenitors and induces Wilms tumor. Genes Dev [Internet]. 2014 May 1 [cited 2015 Dec 20];28(9):971-82. Available from: http://www.pubmedcentral.nih.gov/articlerender.fcgi?artid=4018495\&tool=pm centrez\&rendertype $=$ abstract

108. Perdigão-Henriques R, Petrocca F, Altschuler G, Thomas MP, Le MTN, Tan SM, et al. miR-200 promotes the mesenchymal to epithelial transition by suppressing multiple members of the Zeb2 and Snaill transcriptional repressor complexes. Oncogene [Internet]. Nature Publishing Group; 2016 Jan 23 [cited 2018 Mar 10];35(2):158-72. Available from: http://www.nature.com/articles/onc201569

109. Ruf RG, Xu P-X, Silvius D, Otto EA, Beekmann F, Muerb UT, et al. SIX1 mutations cause branchio-oto-renal syndrome by disruption of EYA1-SIX1DNA complexes. Proc Natl Acad Sci U S A [Internet]. National Academy of Sciences; 2004 May 25 [cited 2018 Mar 3];101(21):8090-5. Available from: http://www.ncbi.nlm.nih.gov/pubmed/15141091

110. Xu P-X, Zheng W, Huang L, Maire P, Laclef C, Silvius D. Six1 is required for the early organogenesis of mammalian kidney. Development [Internet]. 2003 Jul [cited 2015 Dec 24];130(14):3085-94. Available from: http://www.pubmedcentral.nih.gov/articlerender.fcgi?artid=3872112\&tool=pm centrez\&rendertype $=$ abstract

111. Self M, Lagutin O V, Bowling B, Hendrix J, Cai Y, Dressler GR, et al. Six2 is required for suppression of nephrogenesis and progenitor renewal in the developing kidney. EMBO J [Internet]. 2006 Nov 1 [cited 2015 Dec 24];25(21):5214-28. Available from: 
http://www.pubmedcentral.nih.gov/articlerender.fcgi?artid=1630416\&tool=pm centrez\&rendertype $=$ abstract

112. Spreafico F, Ciceri S, Gamba B, Torri F, Terenziani M, Collini P, et al. Chromosomal anomalies at 1q, 3, 16q, and mutations of SIX1 and DROSHA genes underlie Wilms tumor recurrences. Oncotarget [Internet]. Impact Journals, LLC; 2016 Feb 23 [cited 2018 Mar 3];7(8):8908-15. Available from: http://www.ncbi.nlm.nih.gov/pubmed/26802027

113. O'Meara E, Stack D, Lee CH, Garvin AJ, Morris T, Argani P, et al. Characterization of the chromosomal translocation $\mathrm{t}(10 ; 17)(\mathrm{q} 22 ; \mathrm{p} 13)$ in clear cell sarcoma of kidney. J Pathol [Internet]. 2012/02/02 . 2012;227(1):72-80. Available from: http://www.ncbi.nlm.nih.gov/pubmed/22294382

114. Ueno-Yokohata H, Okita H, Nakasato K, Akimoto S, Hata J, Koshinaga T, et al. Consistent in-frame internal tandem duplications of BCOR characterize clear cell sarcoma of the kidney. Nat Genet [Internet]. 2015/06/23. 2015;47(8):861-3. Available from: http://www.ncbi.nlm.nih.gov/pubmed/26098867

115. Inamura K. Translocation Renal Cell Carcinoma: An Update on Clinicopathological and Molecular Features. Cancers (Basel) [Internet]. Multidisciplinary Digital Publishing Institute (MDPI); 2017 Aug 29 [cited 2018 Mar 8];9(9). Available from: http://www.ncbi.nlm.nih.gov/pubmed/28850056

116. Argani P, Lae M, Ballard ET, Amin M, Manivel C, Hutchinson B, et al. Translocation carcinomas of the kidney after chemotherapy in childhood. $\mathrm{J}$ Clin Oncol [Internet]. 2006/04/01. 2006;24(10):1529-34. Available from: http://www.ncbi.nlm.nih.gov/pubmed/16575003

117. Versteege I, Sevenet N, Lange J, Rousseau-Merck MF, Ambros P, Handgretinger R, et al. Truncating mutations of hSNF5/INI1 in aggressive paediatric cancer. Nature [Internet]. 1998/07/22. 1998;394(6689):203-6. Available from: http://www.ncbi.nlm.nih.gov/pubmed/9671307

118. Bourdeaut F, Lequin D, Brugieres L, Reynaud S, Dufour C, Doz F, et al. Frequent hSNF5/INI1 germline mutations in patients with rhabdoid tumor. Clin Cancer Res [Internet]. 2011/01/07. 2011;17(1):31-8. Available from: http://www.ncbi.nlm.nih.gov/pubmed/21208904

119. Knezevich SR, Garnett MJ, Pysher TJ, Beckwith JB, Grundy PE, Sorensen PH. ETV6-NTRK3 gene fusions and trisomy 11 establish a histogenetic link between mesoblastic nephroma and congenital fibrosarcoma. Cancer Res [Internet]. 1998 Nov 15 [cited 2018 Mar 9];58(22):5046-8. Available from: http://www.ncbi.nlm.nih.gov/pubmed/9823307

120. Breslow N, Olshan A, Bechvith JB, Moksness J, Feigl P, Green D. Ethnic Variation in the Incidence, Diagnosis, Prognosis, and Follow-up of Children With Wilms' Tumor. [cited 2018 Mar 15]; Available from: https://watermark.silverchair.com/86-149.pdf?token=AQECAHi208BE49Ooan9kkhW_Ercy7Dm3ZL_9Cf3qfKAc48 5ysgAAAbowggG2BgkqhkiG9w0BBwagggGnMIIBowIBADCCAZwGCSqG SIb3DQEHATAeBglghkgBZQMEAS4wEQQMf5u9hbIntNgZkh8QAgEQgII BbQXQINQ7TeWSclsnJ14xP5Dj_ebAHqQ9Ev3OZNvYqV0rCRdCVDqepoQvEdeKWLp PhsMd6K4P17BEb6cJHwPZWa8KclLnSGxU2hTKzFzZqaICBIDTKb4BYxHcglCpbA5_qFtJtlGkhcKovG5fjJGVh7b2UiRF 10_NeHWuMu8yomafy6ZuhWD19aXbCPMmujIRyJCiX4VJf967Goih21AeM 
hnHU1GOO_VFNjabd6UKa5GIkLXuHOZgHRQIY5ng3rL8ga_yOJKYha1P_ iFRdaR6o7qBo3TPjWYrfCQRwjJbaUrws7NAYd4rSL0HA-

KboXehUSYgt8qPE2UsSa-

qb80RwPaAKGHW9xLOeVqT1g02ahpxcD3qJFg_2S8PL56Eo3_OocF7b-

SOC2h88dWHSSTRfdb90HWfXI6uNBamvdKiT1d8mx6tGQ_vn-

be3eRX3oAO6zTTxDbPZJWhEBv02MQO1SHJ-7zgvtmzIBoIdk

121. Heck JE, Park AS, Contreras ZA, Davidson TB, Hoggatt KJ, Cockburn M, et al. Risk of Childhood Cancer by Maternal Birthplace. JAMA Pediatr [Internet]. American Medical Association; 2016 Jun 1 [cited 2018 Mar 15];170(6):585.

Available from:

http://archpedi.jamanetwork.com/article.aspx?doi=10.1001/jamapediatrics.201 6.0097

122. Howe HL, Wu X, Ries LAG, Cokkinides V, Ahmed F, Jemal A, et al. Annual report to the nation on the status of cancer, 1975-2003, featuring cancer among U.S. Hispanic/Latino populations. Cancer [Internet]. Wiley Subscription Services, Inc., A Wiley Company; 2006 Oct 15 [cited 2018 Mar 15];107(8):1711-42. Available from: http://doi.wiley.com/10.1002/cncr.22193

123. Fukuzawa R, Breslow NE, Morison IM, Dwyer P, Kusafuka T, Kobayashi Y, et al. Epigenetic differences between Wilms' tumours in white and east-Asian children. Lancet [Internet]. 2004 Feb 7 [cited 2018 Mar 15];363(9407):446-51. Available from: http://www.ncbi.nlm.nih.gov/pubmed/14962525

124. Kaneko Y, Okita H, Haruta M, Arai Y, Oue T, Tanaka Y, et al. A high incidence of WT1 abnormality in bilateral Wilms tumours in Japan and the penetrance rates in children with WT1 germline mutation. Br J Cancer [Internet]. Nature Publishing Group; 2015 Mar 17 [cited 2018 Mar 15];112(6):1121-33. Available from: http://www.nature.com/articles/bjc201513

125. Oue T, Koshinaga T, Takimoto T, Okita H, Tanaka Y, Nozaki M, et al. Anaplastic histology Wilms' tumors registered to the Japan Wilms' Tumor Study Group are less aggressive than that in the National Wilms' Tumor Study 5. Pediatr Surg Int [Internet]. Springer Berlin Heidelberg; 2016 Sep 29 [cited 2018 Mar 15];32(9):851-5. Available from: http://link.springer.com/10.1007/s00383-016-3929-7

126. Deng C, Dai R, Li X, Liu F. Genetic variation frequencies in Wilms' tumor: A meta-analysis and systematic review. Cancer Sci [Internet]. Wiley-Blackwell; 2016 May [cited 2018 Mar 15];107(5):690-9. Available from: http://www.ncbi.nlm.nih.gov/pubmed/26892980

127. Jia W, Deng Z, Zhu J, Fu W, Zhu S, Zhang L-Y, et al. Association Between HACE1 Gene Polymorphisms and Wilms' Tumor Risk in a Chinese Population. Cancer Invest [Internet]. Taylor \& Francis; 2017 Nov 26 [cited 2018 Mar 15];35(10):633-8. Available from: https://www.tandfonline.com/doi/full/10.1080/07357907.2017.1405016

128. Fu W, Zhu J, Xiong S-W, Jia W, Zhao Z, Zhu S-B, et al. BARD1 Gene Polymorphisms Confer Nephroblastoma Susceptibility. EBioMedicine [Internet]. 2017 Feb [cited 2018 Mar 15];16:101-5. Available from: http://www.ncbi.nlm.nih.gov/pubmed/28161399

129. Turnbull C, Perdeaux ER, Pernet D, Naranjo A, Renwick A, Seal S, et al. A genome-wide association study identifies susceptibility loci for Wilms tumor. Nat Genet [Internet]. Nature Publishing Group; 2012 Jun 29 [cited 2018 Mar 15];44(6):681-4. Available from: http://www.nature.com/articles/ng.2251 
130. Charlton J, Williams RD, Sebire NJ, Popov S, Vujanic G, Chagtai T, et al. Comparative methylome analysis identifies new tumour subtypes and biomarkers for transformation of nephrogenic rests into Wilms tumour.

Genome Med [Internet]. 2015 Jan [cited 2015 Dec 25];7(1):11. Available from: http://www.pubmedcentral.nih.gov/articlerender.fcgi?artid=4354990\&tool=pm centrez\&rendertype $=$ abstract

131. Gadd S, Huff V, Huang C-C, Ruteshouser EC, Dome JS, Grundy PE, et al. Clinically relevant subsets identified by gene expression patterns support a revised ontogenic model of Wilms tumor: a Children's Oncology Group Study. Neoplasia [Internet]. 2012 Aug [cited 2015 Dec 23];14(8):742-56. Available from:

http://www.pubmedcentral.nih.gov/articlerender.fcgi?artid=3431181\&tool=pm centrez\&rendertype $=$ abstract

132. Pode-Shakked N, Pleniceanu O, Gershon R, Shukrun R, Kanter I, Bucris E, et al. Dissecting Stages of Human Kidney Development and Tumorigenesis with Surface Markers Affords Simple Prospective Purification of Nephron Stem Cells. Sci Rep [Internet]. Nature Publishing Group; 2016 Jul 29 [cited 2018 Mar 16];6(1):23562. Available from: http://www.nature.com/articles/srep23562

133. Brok J, Pritchard-Jones K, Geller JI, Spreafico F. Review of phase I and II trials for Wilms' tumour - Can we optimise the search for novel agents? Eur J Cancer [Internet]. 2017 Jul [cited 2017 Jun 29];79:205-13. Available from: http://www.ncbi.nlm.nih.gov/pubmed/28521171

134. Pediatric MATCH: Targeted Therapy Directed by Genetic Testing in Treating Pediatric Patients With Relapsed or Refractory Advanced Solid Tumors, NonHodgkin Lymphomas, or Histiocytic Disorders - Full Text View ClinicalTrials.gov [Internet]. [cited 2018 Feb 7]. Available from: https://clinicaltrials.gov/ct2/show/NCT03155620?term=wilms\&recrs=ab\&cond $=$ Nephroblastoma\&draw $=3 \&$ rank $=23$

135. Gustafson WC, Meyerowitz JG, Nekritz EA, Chen J, Benes C, Charron E, et al. Drugging MYCN through an Allosteric Transition in Aurora Kinase A. Cancer Cell [Internet]. 2014 Sep 8 [cited 2018 Mar 13];26(3):414-27. Available from: http://www.ncbi.nlm.nih.gov/pubmed/25175806

136. Wetmore C, Boyett J, Li S, Lin T, Bendel A, Gajjar A, et al. Alisertib is active as single agent in recurrent atypical teratoid rhabdoid tumors in 4 children. Neuro Oncol [Internet]. Oxford University Press; 2015 Jun [cited 2018 Mar 13];17(6):882-8. Available from: http://www.ncbi.nlm.nih.gov/pubmed/25688119

137. DuBois SG, Marachelian A, Fox E, Kudgus RA, Reid JM, Groshen S, et al. Phase I Study of the Aurora A Kinase Inhibitor Alisertib in Combination With Irinotecan and Temozolomide for Patients With Relapsed or Refractory Neuroblastoma: A NANT (New Approaches to Neuroblastoma Therapy) Trial. J Clin Oncol [Internet]. 2016 Apr 20 [cited 2018 Mar 13];34(12):1368-75. Available from: http://www.ncbi.nlm.nih.gov/pubmed/26884555

138. Yaari S, Jacob-Hirsch J, Amariglio N, Haklai R, Rechavi G, Kloog Y. Disruption of Cooperation Between Ras and $\mathrm{MycN}$ in Human Neuroblastoma Cells Promotes Growth Arrest. Clin Cancer Res [Internet]. 2005 Jun 15 [cited 2018 Mar 13];11(12):4321-30. Available from: http://www.ncbi.nlm.nih.gov/pubmed/15958613

139. Cox AD, Fesik SW, Kimmelman AC, Luo J, Der CJ. Drugging the 
undruggable RAS: Mission Possible? Nat Rev Drug Discov [Internet]. Nature Publishing Group; 2014 Nov 17 [cited 2018 Mar 13];13(11):828-51. Available from: http://www.nature.com/articles/nrd4389

140. Dalpa E, Gourvas V, Soulitzis N, Spandidos DA. K-Ras, H-Ras, N-Ras and BRaf mutation and expression analysis in Wilms tumors: association with tumor growth. Med Oncol [Internet]. Springer US; 2017 Jan 9 [cited 2018 Mar 13];34(1):6. Available from: http://link.springer.com/10.1007/s12032-0160862-5

141. Clark PE, Polosukhina D, Love H, Correa H, Coffin C, Perlman EJ, et al. $\beta$ Catenin and K-RAS synergize to form primitive renal epithelial tumors with features of epithelial Wilms' tumors. Am J Pathol [Internet]. American Society for Investigative Pathology; 2011 Dec [cited 2018 Mar 13];179(6):3045-55. Available from: http://www.ncbi.nlm.nih.gov/pubmed/21983638

142. Cramer SL, Miller AL, Pressey JG, Gamblin TL, Beierle EA, Kulbersh BD, et al. Pediatric Anaplastic Embryonal Rhabdomyosarcoma: Targeted Therapy Guided by Genetic Analysis and a Patient-Derived Xenograft Study. Front Oncol [Internet]. Frontiers; 2018 Jan 11 [cited 2018 Mar 13];7:327. Available from: http://journal.frontiersin.org/article/10.3389/fonc.2017.00327/full

143. Burgess A, Chia KM, Haupt S, Thomas D, Haupt Y, Lim E. Clinical Overview of MDM2/X-Targeted Therapies. Front Oncol [Internet]. Frontiers Media SA; 2016 [cited 2017 Feb 28];6:7. Available from: http://www.ncbi.nlm.nih.gov/pubmed/26858935

144. Lorvotuzumab Mertansine in Treating Younger Patients With Relapsed or Refractory Wilms Tumor, Rhabdomyosarcoma, Neuroblastoma, Pleuropulmonary Blastoma, Malignant Peripheral Nerve Sheath Tumor, or Synovial Sarcoma - Full Text View - ClinicalTrials.gov [Internet]. [cited 2015 Dec 19]. Available from: https://clinicaltrials.gov/ct2/show/NCT02452554

145. Pode-Shakked N, Shukrun R, Mark-Danieli M, Tsvetkov P, Bahar S, Pri-Chen $\mathrm{S}$, et al. The isolation and characterization of renal cancer initiating cells from human Wilms' tumour xenografts unveils new therapeutic targets. EMBO Mol Med [Internet]. EMBO Press; 2013 Jan [cited 2016 Jun 19];5(1):18-37. Available from: http://embomolmed.embopress.org/cgi/doi/10.1002/emmm.201201516

146. Forbes SA, Beare D, Boutselakis H, Bamford S, Bindal N, Tate J, et al. COSMIC: somatic cancer genetics at high-resolution. Nucleic Acids Res [Internet]. Oxford University Press; 2017 Jan 4 [cited 2018 Apr 8];45(D1):D777-83. Available from: https://academic.oup.com/nar/articlelookup/doi/10.1093/nar/gkw1121 